\title{
Ferramenta educativa sobre citologia oncótica na Atenção Primária
}

\author{
Educational tool on oncotic cytology in Primary Care \\ Herramienta educativa sobre citología oncológica en Atención Primaria
}

\section{Resumo}

Objetivo: elaborar ferramenta educativa sobre citologia oncótica na atenção primária à saúde. Método: trata-se de estudo metodológico de desenvolvimento de ferramenta educativa com abordagem quantiqualitativa, por meio do Índice de Validade de Conteúdo e do Alpha de Cronbach. Resultados: Na rodada Delphi I, quanto a clareza, dez questões não obtiveram pontuação mínima de 0,80 e quanto a relevância, foram aprovadas apenas quatro. Na etapa Delphi II, todos os itens foram aprovados. Quanto ao Alpha de Cronbach, houve significância estatística na rodada Delphi I $(\mathrm{p} \leq 0,05)$. Na rodada Delphi II, embora o resultado não tenha se mostrado estatisticamente significativo nos dois critérios, as modificações realizadas e as exclusões dos itens permitiram elevar o valor do índice nas duas condições. Conclusão: O resumo de protocolos oficiais, seguido da sua compilação na forma de folheto educativo contribui para a fácil disseminação do conhecimento acerca das técnicas de coleta de citologia oncótica.

Palavras-chave: Tecnologia; Teste de Papanicolau; Neoplasias do colo do útero; Atenção Primária à Saúde.

\begin{abstract}
Objective: to develop an educational tool on oncotic cytology in primary health care. Method: this is a methodological study for the development of an educational tool with a quanti-qualitative approach, using the Content Validity Index and Cronbach's Alpha. Results: In the Delphi I round, regarding clarity, ten questions did not obtain a minimum score of 0.80 and regarding relevance, only four were approved. In the Delphi II step, all items were approved. As for Cronbach's Alpha, there was statistical significance in the Delphi I round $(\mathrm{p} \leq 0.05)$. In the Delphi II round, although the result was not statistically significant in the two criteria, the modifications made and the exclusions of the items allowed the index to be raised in both conditions. Conclusion: The summary of official protocols, followed by their compilation in the form of an educational brochure contributes to the easy dissemination of knowledge about oncotic cytology collection techniques.
\end{abstract}

Keywords: Technology; Papanicolau test; Uterine cervical neoplasy; Primary Health Care.

\section{Resumen}

Objetivo: desarrollar una herramienta educativa sobre citología oncótica en la atención primaria de salud. Método: se trata de un estudio metodológico de desarrollo de herramientas educativas con abordaje cuantitativo, mediante el Índice de Validez de Conteúdo y el Alpha de Cronbach. Resultados: En la ronda Delphi I, en cuanto a claridad, diez preguntas no obtuvieron una puntuación mínima de 0,80 y en cuanto a relevancia, sólo se aprobaron cuatro. En la 
etapa Delphi II, todos los elementos fueron aprobados. En cuanto al Alfa de Cronbach, hubo significación estadística en la ronda Delphi I $(p \leq 0,05)$. En la ronda Delphi II, aunque el resultado no resulto ser estadísticamente significativo en ambos criterios, las modificaciones realizadas y las exclusiones de los ítems permitieron aumentar el valor del índice en ambas condiciones. Conclusión: El resumen de los protocolos oficiales, seguido de su recopilación en forma de folleto educativo, contribuye a la fácil difusión de los conocimientos sobre las técnicas de recogida de citología oncótica.

Palabras clave: Tecnología; Prueba de Papanicolau; Neoplasias de cuello uterino; Atención Primaria de la Salud.

\section{Introdução}

Em nível global, a Organização das Nações Unidas (Onu, 2019) adotou uma mudança conceitual para os Objetivos de Desenvolvimento do Milênio, atualizando para os Objetivos do Desenvolvimento Sustentável. (ODS) Neste novo paradigma, o terceiro objetivo trata da saúde e bem-estar dos indivíduos e coletividades, a fim de reduzir o impacto das enfermidades sobre as pessoas, por meio de estratégias relacionadas ao combate de doenças crônicas transmissíveis e não transmissíveis até 2030. (ONU, 2019)

Em relação às doenças crônicas, em especial as crônico-degenerativas, os cânceres possuem destaque quanto ao efeito negativo sobre a vida do indivíduo, devido ao diagnóstico e a condução terapêutica. Sobre isso, o câncer de colo uterino, também chamado de neoplasia cervical, está entre as principais causas de morte entre as mulheres brasileiras, sendo julgada a quarta causa de mortalidade entre mulheres no mundo, considerando somente as mortes por câncer. A incidência dessa doença é tão elevada que os tumores decorrentes dela se constituem na terceira maior frequência entre a população feminina, perdendo apenas para o câncer de mama e o colorretal. (Inca, 2020)

As alterações desse tipo de câncer são descobertas facilmente no exame preventivo, conhecido popularmente como Papanicolau. Na maioria das vezes, essas anomalias são curáveis na quase totalidade dos casos. Por essa razão, a coleta adequada, a partir da realização periódica desse exame se constitui na principal via de detecção, contribuindo para o prolongamento da vida com qualidade das mulheres. O exame citológico, assim também como a colposcopia, devem ser cada vez mais valorizados como método de rastreio para evitar o câncer de colo de útero, já que se trata de uma importante causa de morte por câncer de mulheres, não somente no Brasil, mas em todo o mundo. (Who, 2019) Em meio a esta problemática, o Ministério da Saúde do Brasil convoca a população a se submeter à coleta de citologia oncótica dos 25 aos 64 anos, que consiste na faixa etária com maior prevalência do câncer de colo uterino. (Inca, 2016a)

Considerando que o câncer de colo uterino constitui importante causa de morte entre as mulheres brasileiras e que a citologia oncótica é falha em até 50\% dos resultados (Inca, 2018a), o profissional de saúde deve possuir qualificação profissional para proceder à coleta adequada. O INCA recomenda que a coleta seja realizada por profissionais de saúde especializados, significando que o sucesso da detecção precoce do câncer de colo de útero e suas lesões precursoras dependem do seu treinamento eficiente. (Brasil, 2016)

Sobre inovação em saúde, uma ferramenta educacional pode ter impacto direto na melhoria da coleta da citologia oncótica e na capacidade de encaminhamento das pacientes pelos profissionais para a atenção especializada à saúde, tendo como efeito indireto a detecção precoce do HPV e consequentemente, diminuição da morbimortalidade por câncer de colo uterino. Para tanto, este estudo se justifica pela necessidade de construir uma tecnologia em saúde capaz de facilitar o conhecimento dos profissionais de saúde para uma detecção precoce mais eficiente das lesões precursoras do câncer de colo uterino, dentro das unidades básicas de saúde de cada região, com impacto direto na redução da morbimortalidade por câncer de colo uterino do Brasil.

Assim, considerando que a saúde e bem-estar populacional é um objetivo global, entendendo que os agravos decorrentes do câncer de colo uterino têm sido frequentes no Brasil e no mundo, atentando que a PNCTIS incentiva a criação de ferramentas inovadoras no âmbito das prioridades da pesquisa em saúde e acreditando que o acesso à informação sobre pré- 
coleta, bem como a técnica correta, além de orientações sobre o armazenamento, transporte e leitura da lâmina possam minimizar o alto índice de falso negativo do exame de Papanicolau, este estudo é norteado pelo seguinte questionamento: Tecnologia educativa sobre técnica correta de coleta da citologia oncótica, orientações sobre o preparo adequado da usuária, armazenamento, transporte e leitura da lâmina pode auxiliar as práticas dos profissionais de saúde na atenção básica? Para tanto, objetivou-se elaborar ferramenta educativa sobre citologia oncótica voltada aos profissionais da atenção primária à saúde.

\section{Metodologia}

Pesquisa metodológica com abordagem mista de desenvolvimento de ferramenta educativa para melhoria do processo de ensino-aprendizagem. Para construção de tecnologias sob o formato de instrumentos, ferramentas e técnicas, tornou-se necessário o seguimento de um referencial técnico-metodológico. Neste estudo, adotou-se o referencial metodológico de Pasquali (2017), conforme ilustrado na Figura 1, para direcionamento da construção e validação do recurso tecnológico educacional.

A Figura 1 consiste na síntese metodológica deste estudo.

Figura 1. Esquematização das etapas para construção e validação do recurso tecnológico educacional. João Pessoa, Paraíba, Brasil. 2018.

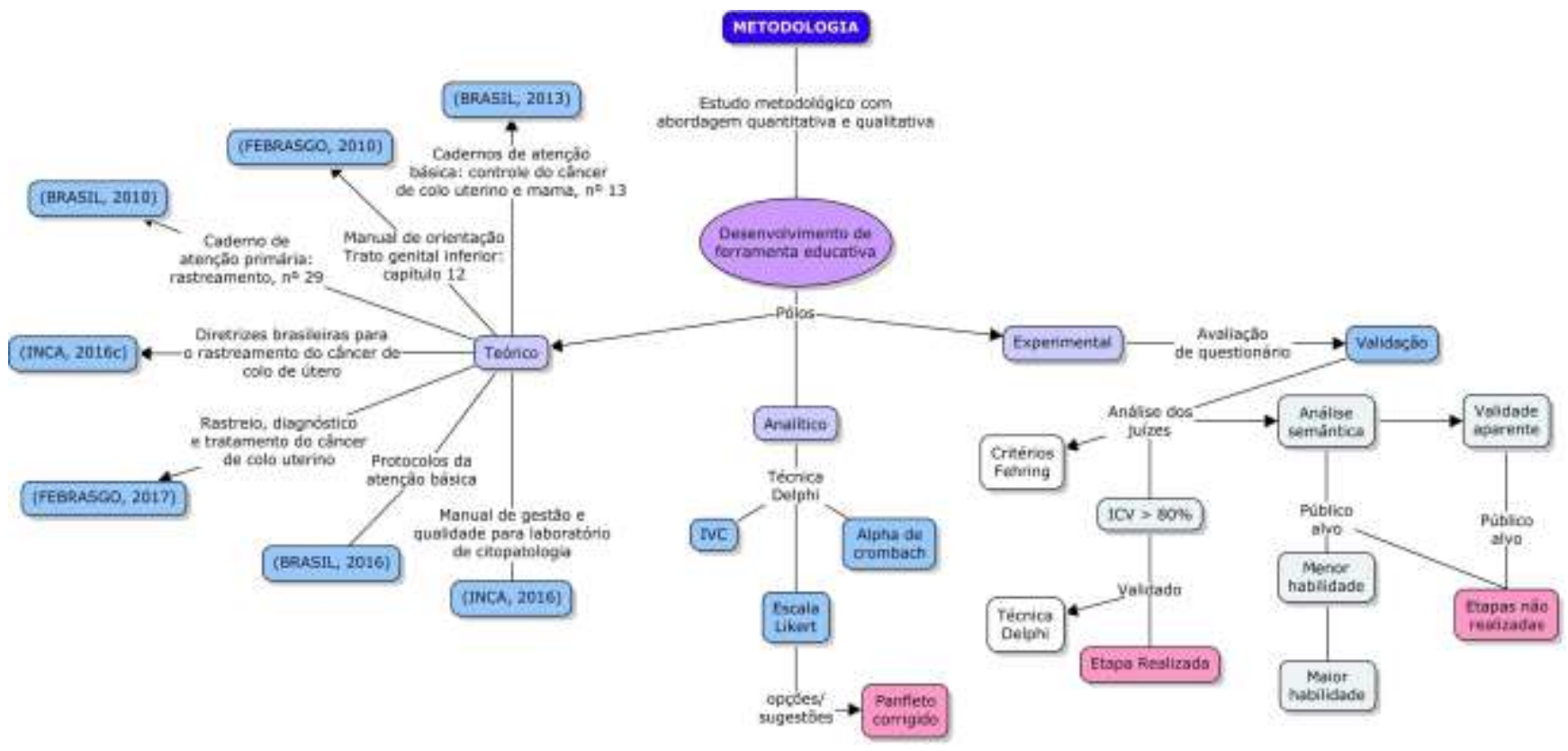

Fonte: Elaboração Própria.

Para validação da ferramenta, foram convidados juízes especialistas na área, cuja seleção fora respaldada nos critérios adaptados do Modelo de Fehring, que lida com condições relevantes à escolha de pessoas especialistas na área objeto. A amostra foi constituída de seis profissionais da saúde, considerados como peritos na área. Estes, para serem considerados peritos, deveriam possuir experiência clínica na área de citologia oncótica/patologia do trato genital inferior superior a um ano de atividade profissional, ter mestrado ou doutorado na área, entre outros critérios expostos no quadro 1 . Conforme o modelo, a pontuação mínima é de 5 e máxima de 14 pontos. Juízes abaixo da pontuação mínima foram considerados pouco conhecedores da temática, sendo, portanto, excluídos da avaliação, (Fehring, 1987).

O Quadro 1 apresenta os critérios utilizados neste estudo. 
Quadro 1. Critérios adaptados do Modelo de Fehring, 1987.

\section{CRITÉRIOS}

Titulação de mestre em Enfermagem/ Medicina

Dissertação direcionada à temática abordada

Publicação com o tema da dissertação em periódicos de referência na sua área enquanto autor principal

Artigo publicado com conteúdo relevante à área abordada, enquanto autor secundário/ orientador.

Titulação de doutor, com conteúdo relevante à área abordada (Enfermagem/ Medicina).

Experiência clínica de, pelo menos, um ano na área de Citologia Oncótica/ Patologia do Trato Genital Inferior/ Colposcopia.

Especialização com trabalho final utilizando o tema abordado.

\section{PONTUAÇÃO}

4 pontos

1 ponto

2 pontos

2 pontos

2 pontos

1 ponto

2 pontos

Fonte: Elaboração Própria.

Os peritos foram selecionados através do currículo Lattes, artigos publicados e sites de instituições nas quais trabalhavam e escolhidos aqueles que atingiram pontuação acima de cinco, de acordo com os critérios estabelecidos por Fehring (1987). A pesquisa no currículo foi feita através das palavras-chave: citologia oncótica; mestrado; doutorado; artigos de câncer de colo uterino/ citologia oncótica/ HPV; experiência clínica em patologia trato genital inferior/ citologia oncótica.

Após a varredura no Currículo Lattes, os endereços eletrônicos foram coletados para realização do convite oficial com o instrumento. Além disso, caso existisse possibilidade, os juízes foram contatados primeiramente por via telefônica, para conferir maior celeridade ao processo de avaliação. Mediante resposta positiva, receberam o Termo de Consentimento Livre e Esclarecido (TCLE), sendo enviados por meio de correio eletrônico.

A técnica de amostragem não probabilística escolhida foi tipo bola de neve, que consiste na escolha dos sujeitos, tendo seu início através de um ou vários sujeitos escolhidos (Richardson, 2017) de acordo com o seu currículo, levando em consideração os critérios de Fehring. Neste estudo, houve inicialmente três sementes, que foram os primeiros juízes, devendo estes indicar outros três para realizarem a validação juntamente com os primeiros. Esta indicação esteve de acordo com as características desejadas para o estudo, sendo apontados a partir do conhecimento pessoal de cada juiz. Entende-se por sementes documentos ou pessoas essenciais ao início da pesquisa (Vinuti, 2014). Para construção do instrumento, houve a compilação dos documentos oficiais sobre o câncer de colo uterino e elaboração dos mapas conceituais.

O polo teórico foi elaborado por meio de leitura e revisão de sete documentos institucionais mais atuais do Brasil sobre a temática, quais sejam: Caderno de Atenção Primária: Rastreamento, número 29 (Brasil, 2010); Manual de Orientação Trato Genital Inferior: capítulo 12 - Rastreamento para câncer de colo uterino no Brasil (Febrasgo, 2010); Caderno de Atenção Básica: Controle dos Cânceres de colo uterino e mama, número 13 (Brasil, 2013); Diretrizes Brasileiras para o Rastreamento do Câncer do Colo do Útero (Inca, 2016c); Manual de Gestão e Qualidade para Laboratório de Citopatologia (Inca, 2016d); Protocolos da Atenção Básica (Brasil, 2016b); Rastreio, Diagnóstico e Tratamento do Câncer de Colo de Útero (Febrasgo, 2017);

Os downloads dos documentos supracitados foram realizados por meio de sítios online oficiais das instituições governamentais que lidam com a temática, tais como Ministério da Saúde, Instituto Nacional do Câncer e Federação Brasileira das Associações de Ginecologia e Obstetrícia - Febrasgo (2017). Após a leitura, elaboraram-se quadros com as informações pré-coleta (Quadro 2), condutas durante o exame (Quadro 3) e tomada de decisão frente aos resultados da citologia oncótica (Quadro 4). O quadro possuía além destas informações, o nome do documento e a página consultada, para viabilizar a consulta e fornecer certeza ao leitor, daquilo que foi contemplado na compilação das orientações. 
Após a elaboração do compilado de maneira ampla, procedeu-se à síntese das informações governamentais sob o formato de mapas conceituais, em número de quatro, extraindo-se as informações mais relevantes em forma de tópicos autoexplicativos, de forma a subsidiar a criação da ferramenta educativa. O primeiro mapa refere-se às recomendações prévias à coleta de citologia oncótica, que expõe quais mulheres devem ser submetidas ao exame, de acordo com condições clínicas específicas de cada caso. O segundo mapa faz referência aos procedimentos referentes à coleta, especificando a técnica correta antes, durante e após o exame. Por fim, no terceiro e quarto mapa, especificam- se os resultados e condutas iniciais para cada caso, levando em consideração o resultado da citologia oncótica. Os esboços dos mapas conceituais foram criados de maneira elementar pelo programa Cmap Tools, versão 6.01. Eles serviram de material-apoio à empresa de criação de mídias Mold Studio, à qual inseriu os recursos de imagens para conferir grau de ludicidade aos mapas conceituais, bem como organização estética.

O folheto foi reproduzido em 2 folhas sulfite tamanho A4, frente e verso, anexadas dobradas ao meio, na forma de livro, totalizando 8 espaços contendo os 4 mapas conceituais, além da capa e esclarecimentos sobre objetivos e público-alvo. $\mathrm{O}$ material tem importância singular, pois traz a compilação das recomendações nacionais mais recentes sobre o assunto, inclusive orientações quanto à tomada de decisão frente aos resultados da citologia. Revela- se importante instrumento orientador do profissional responsável pela coleta da citologia oncótica, que pode consultá-lo sempre que necessário.

A construção e aplicação deste folheto educativo estão em consonância com a Política Nacional de Ciência, Tecnologia e Inovação em Saúde (PNCTIS) e com a Agenda Nacional de Prioridades de Pesquisa em Saúde (ANPPS), pois almeja auxiliar na redução da morbimortalidade das mulheres brasileiras. Com isso, busca respeitar o princípio da equidade $\mathrm{e}$ melhorar as condições de saúde da população, respeitando sua vida e dignidade. Também se compromete a não ferir os princípios éticos de pesquisa em saúde, respeitando os indivíduos envolvidos, tendo como responsabilidade evitar qualquer dano à saúde dos atores envolvidos no processo.

A elaboração do questionário teve como base o folheto desenvolvido pelo designer. Para elaborar os quesitos, o folheto foi fragmentado e inserido no questionário para avaliação e sugestão do perito. Esta etapa consistiu na rodada Delphi I, que pode ser entendida como técnica para coleta de opiniões de peritos especializados em determinado assunto, a fim de um consenso sobre o assunto abordado. Após a sugestão dos peritos e levando em consideração o IVC individual de cada quesito foram feitas modificações e exclusões no questionário, tendo sido refeito e reenviado aos juízes para sua nova avaliação. Cumpridos os valores considerados mínimos de IVC, os itens foram aprovados. Concluiu-se, desta maneia, a rodada Delphi II, elaborando-se-o folheto em seu formato final.

O questionário enviado via e-mail, foi respondido também por esta via em um prazo de até 15 dias úteis. O questionário constou quesitos, que seguiram a escala tipo Likert e responderam de acordo com sua avaliação sobre os mapas conceituais construídos para fins de melhoramento da compreensão por parte dos profissionais que a utilizarem. Os resultados foram baseados em análise de concordância.

Para a análise de concordância, foi utilizado o Índice de Validade de Conteúdo (IVC) que corresponde a uma análise muito empregada na área de saúde, no qual se avalia a porcentagem de juízes que estão em anuência sobre determinados ângulos do instrumento e de seus itens (Hyrkäs et al., 2003).

Consente primeiramente analisar cada item separadamente e depois o instrumento como um todo. Este método emprega uma escala tipo Likert com pontuação de um a quatro. Para julgar a pertinência, as respostas podem incluir: $1=$ não relevante ou não representativo, $2=$ item necessita de grande revisão para ser representativo, $3=$ item necessita de pequena revisão para ser representativo, 4 = item relevante ou representativo (Rubio et al., 2003). 
O cálculo é feito através da soma de concordância dos itens que foram indicados por "3" ou "4" pelos expertises. Os itens que receberam pontuação "1" ou "2" devem ser revisados ou eliminados. Desta maneira, o IVC tem sido também determinado como "a proporção de itens que recebe uma pontuação de 3 ou 4 pelos juízes" (Wynd et al., 2003).

A coleta dos dados da validação dos juízes ocorreu por meio da técnica Delphi. Após a escolha destes expertises, os mesmos podem responder ao questionário pré-elaborado, de forma não-presencial e anônima entre si, emitindo sua opinião e sugestão sobre as questões (Munaretto et al., 2013). A análise dos dados ocorreu com uso do software IBM SPSS, versão 21, por meio do Índice de Validade de Conteúdo e do Alpha de Cronbach. Para classificar Confiabilidade do Alfa de Cronbach utiliza-se os seguintes parâmetros: Muito baixa $(\alpha \leq 0,30)$; Baixa $(0,30<\alpha \leq 0,60)$; Moderada $(0,60<\alpha \leq 0,75)$; Alta $(0,75<\alpha$ $\leq 0,90)$ e Muito alta $(\alpha>0,90)$. Quanto maior a proximidade de 1 , maior a confiabilidade entre os indicadores. O limite inferior comumente aceito é 0,7 (Gottems et al., 2018). Após análise das sugestões feitas, os mapas foram refeitos e novamente encaminhados para os peritos, afim da chegada de um consenso de $80 \%$ entre eles. Com isso, o produto final foi concluído, podendo o folheto ser impresso em seu formato final.

O estudo respeitou as diretrizes e critérios estabelecidos na Resolução 466/12 do Conselho Nacional de Saúde (CNS), que versa sobre pesquisas envolvendo seres humanos. Foi submetido ao Comitê de Ética, em concordância com Conselho de Ética Médica, resolução CFM n 1931/2009 e da Resolução 564/2017, relativa ao Código de Ética dos Profissionais de Enfermagem, sendo aprovada conforme protocolo 196/2019 e CAAE: 24990819.1.0000.5179.

A presente pesquisa não possui riscos previsíveis, ela poderia causar desconforto aos juízes, pois requer conhecimento prévio das recomendações resumidas em questão, podendo gerar conflitos entre o conhecimento e prática. Em relação aos benefícios, a pesquisa se constitui como passo incipiente à elaboração de uma ferramenta educativa em prol da deteç̧ão precoce do câncer de colo uterino em âmbito municipal, trazendo subsídios para redução das taxas de morbimortalidade na população. O folheto foi registrado na protocolado pelo número 22.188/2020 e licenciado com uma Licença Creative Commons Atribuição 4.0 Internacional.

\section{Resultados e Discussão}

A compilação dos documentos oficiais sobre citologia oncótica pode ser visualizada no Quadro 2 adiante.

Quadro 2. Recomendações prévias relacionadas ao câncer de colo uterino. João Pessoa, Paraíba, Brasil. 2018. (N=5).

\begin{tabular}{|c|c|}
\hline $\begin{array}{c}\text { DOCUMENTO } \\
\text { OFICIAL } \\
\end{array}$ & INFORMAÇÕES \\
\hline BRASIL (2010) & $\begin{array}{l}\text { PÁGINA 68 } \\
\text { - Rastreamento de câncer do colo do útero de mulheres sexualmente ativas e que tenham a cérvice. } \\
\text { - Contra o rastreamento de rotina de câncer do colo do útero em mulheres maiores de } 65 \text { anos que tiveram um } \\
\text { resultado normal, não estão no grupo de alto risco e com histerectomia total. } \\
\text { PÁGINA 70 } \\
\text { - O intervalo entre os exames deve ser de três anos, após dois exames negativos, com intervalo anual. }\end{array}$ \\
\hline FEBRASGO (2010) & $\begin{array}{l}\text { PÁGINA } 146 \text { e } 148 \\
\text { - Intervalo de } 3 \text { anos após três citologias anuais normais. } \\
\text { Situações Especiais: } \\
\text { - Controle anual para mulheres imunossuprimidas ou expostas a dietil-etilbestrol. } \\
\text { - Após iniciação sexual de mulheres soropositivas, rastreamento semestral no primeiro ano após o diagnostico e, se } \\
\text { normais, manter seguimento anual independentemente da orientação sexual declarada. } \\
\text { - Controle anual para mulheres tratadas de neoplasia intraepitelial de alto grau ou câncer. } \\
\text { - Continua... } \\
\text { por atrofia deve-se proceder a estrogenização tópica por } 14 \text { dias e repetir a coleta. } \\
\text { - Mulheres com histerectomia total sem história prévia de lesões cervicais de alto grau devem ser excluídas do } \\
\text { rastreamento, desde que tenham três exames anteriores normais. }\end{array}$ \\
\hline
\end{tabular}


BRASIL (2013)

- O intervalo entre os exames deve ser de três anos, após dois exames negativos, com intervalo anual.

- Após iniciação sexual, iniciar o rastreamento aos 25 anos.

- Os exames devem seguir até os 64 anos. Após essa idade, não realizar se pelo menos houve dois exames negativos consecutivos nos últimos cinco anos.

- Para as mulheres que nunca realizaram o exame até 64 anos, realizar dois exames com intervalo de um a três anos. Se ambos forem negativos, dispensa do rastreamento.

\section{PÁGINA 55}

- Gestantes:

A coleta endocervical com técnica adequada não parece oferecer risco.

Recomendação: o rastreamento em gestantes deve seguir as recomendações de periodicidade e faixa etária como para as demais mulheres. A realização de pré-natal deve ser uma oportunidade para o rastreio.

\section{PÁGINA 56}

- Mulheres na pós-menopausa devem ser rastreadas conforme orientações gerais. Caso necessário, proceder à estrogenização prévia à realização da coleta.

- Mulheres com histerectomia total sem história prévia de lesões cervicais de alto grau devem ser excluídas do rastreamento, desde que tenham exames anteriores normais. Em casos de histerectomia por lesão precursora ou câncer cervical, a mulher deverá ser acompanhada de acordo com a lesão tratada.

- Não há indicação de rastreamento para mulheres sem história de atividade sexual.

\section{PÁGINA 57}

\section{IMUNOSSUPRIMIDAS}

- Realizar o exame após o início da atividade sexual com intervalos semestrais no primeiro ano e, se normais, manter seguimento anual enquanto se mantiver o fator de imunossupressão.

- Controle semestral de mulheres HIV positivas com $\mathrm{CD}^{+}$abaixo de 200 células $/ \mathrm{mm}^{3}$ após correção dos níveis de $\mathrm{CD}^{+}$.

\section{PÁGINA 60}

- Evitar uso de lubrificantes, espermicidas, medicamentos vaginais e realização de exame intravaginal com gel para transdutor por 48 horas antes da coleta para não dificultar a avaliação microscópica.

- A recomendação de abstinência sexual prévia ao exame só é justificada quando são utilizados preservativos com lubrificante ou espermicidas. Na prática, a presença de espermatozoides não compromete a avaliação microscópica.

- O exame não deve ser feito no período menstrual, pois a presença de sangue pode prejudicar o diagnóstico citopatológico. Deve-se aguardar o quinto dia após o término da menstruação.

- No caso de sangramento vaginal anormal, o exame ginecológico é mandatório e a coleta, se indicada, pode ser realizada.

\section{PÁGINA 62}

Preparação da lâmina:

- a lâmina e o frasco ou caixa de porta-lâminas devem ser preparados previamente.

- O uso de lâmina com bordas lapidadas e extremidade fosca é obrigatório. Verificar se a lâmina está limpa e, caso necessário, limpá-la com gaze; a lâmina deve ser identificada com as iniciais do nome da mulher e o seu número de registro na unidade, com lápis preto $\mathrm{n}^{\circ} 2$ ou grafite, na extremidade fosca. Não usar caneta hidrográfica ou esferográfica, pois as tintas se dissolvem durante o processo de coloração das lâminas no laboratório.

BRASIL (2016b)

- O frasco ou a caixa de porta-lâmina devem ser identificados a lápis.

PÁGINA 176

- Preencher a requisição de exame citopatológico do colo do útero (ficha).

- Realização de coleta de material citológico conforme normas de coleta padronizadas pelo Inca e Caderno de Atenção Básica $\mathrm{n}^{\circ} 13$.

- Idealmente, a coleta deve ocorrer pelo menos cinco dias após o término da menstruação. Caso seja a

única oportunidade de rastreio com a mulher menstruada, adicionar gotas de ácido acético a $2 \%$ à solução fixadora, para melhorar a qualidade da amostra.

- Na identificação de quaisquer anormalidades durante o procedimento de coleta é imprescindível a

avaliação do(a) enfermeiro(a) e/ou médico(a).

Continua...

- Informar sobre a possibilidade de discreto sangramento após a coleta, com cessação espontânea.

- Orientação sobre a importância de buscar o resultado do exame.

- Agendamento do retorno para o resultado.

- Na presença de secreção vaginal anormal, friabilidade do colo, efetuar coleta para análise laboratorial e tratar de acordo com abordagem sindrômica. Seguir a rotina de rastreamento, independentemente desta abordagem.

- Prescrição de tratamento para outras doenças detectadas, como IST, caso presentes, na oportunidade de rastreamento.

- Na presença de lesões suspeitas (vegetantes ou ulceradas), queixa de sangramento vaginal fora do período menstrual e/ou desencadeada pela relação sexual, encaminhar para avaliação especializada, visto que podem ser manifestações de doença invasora. A citologia, nesses casos, devido à necrose tecidual, pode não identificar a presença de células neoplásicas.

PÁGINA 182

- Após dois exames normais anuais consecutivos, o intervalo poderá ser de três anos.

Coleta de citologia em situações especiais 


\begin{tabular}{|c|c|}
\hline & 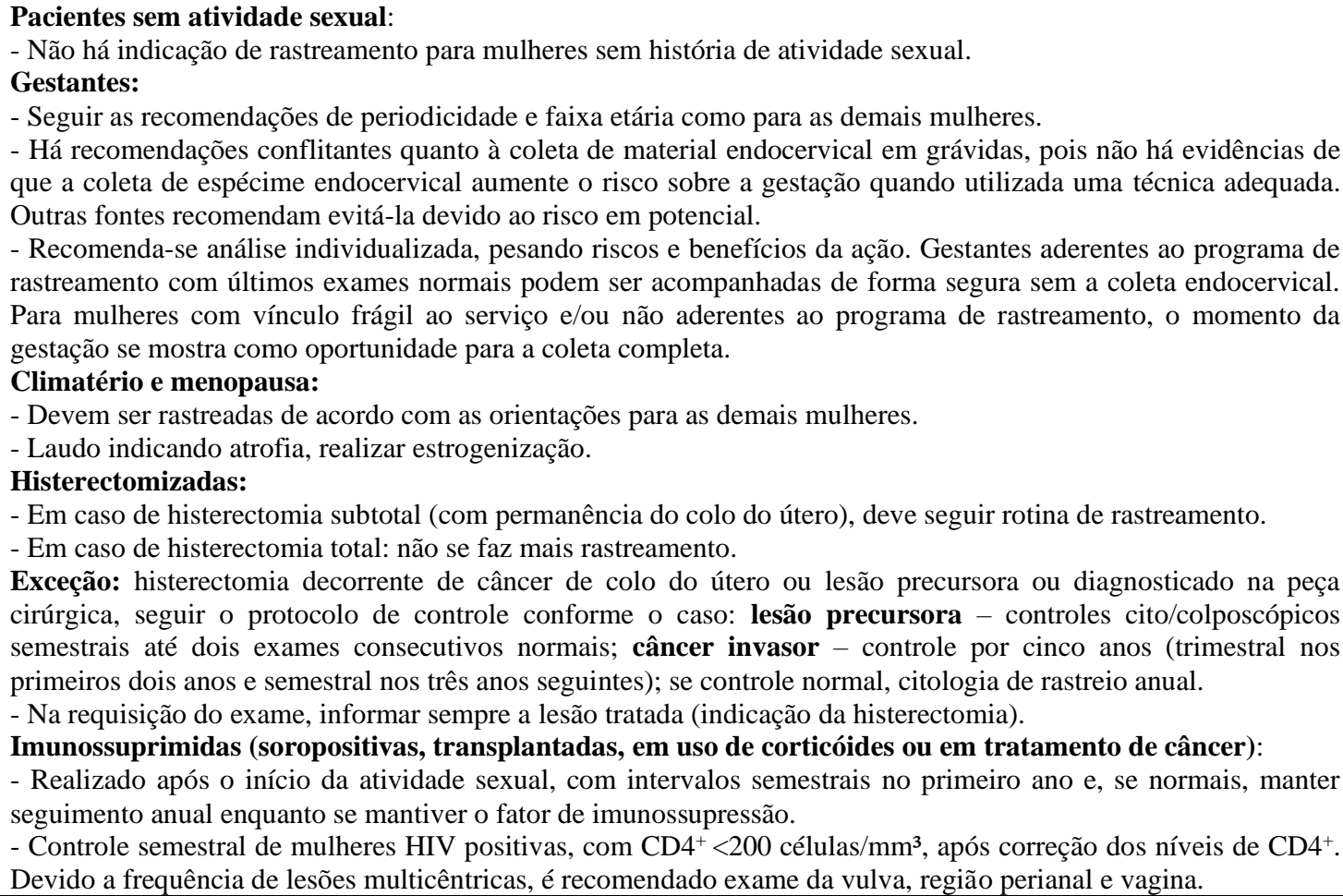 \\
\hline FEBRASGO (2017) & $\begin{array}{l}\text { PÁGINA 15 } \\
\text { - Após dois exames negativos realizados com intervalo de um ano, realizar exame a cada } 3 \text { anos. Evitar o } \\
\text { diagnóstico e tratamento de lesões precursoras assintomáticas por rastreamento em mulheres < } \mathbf{2 5} \text { anos. } \\
\text { - Interromper rastreamento em mulheres com } 64 \text { anos tendo pelo menos dois exames negativos consecutivos nos } \\
\text { últimos cinco anos e sem história prévia de câncer cervical. A estrogenização prévia a coleta pode ser realizada em } \\
\text { mulheres na pós-menopausa. } \\
\text { - Mulheres com histerectomia total sem história prévia de lesões cervicais de alto grau devem ser } \\
\text { excluídas do rastreamento, desde que tenham exames anteriores normais. } \\
\text { - Em mulheres imunossuprimidas o exame citológico deve ser realizado após o início da atividade sexual com } \\
\text { intervalos semestrais no primeiro ano e, se normais, manter seguimento anual enquanto se } \\
\text { mantiver o fator de imunossupressão. } \\
\text { - Rastreamento semestral para soropositivas. } \\
\text { - Algumas recomendações nacionais e internacionais recomendam o uso de teste de detecção do HPV, associados } \\
\text { à citologia, em mulheres } \geq 30 \text { anos. } \\
\text { - Sucesso do rastreamento depende da realização periódica do exame; convite para realizar o exame a cada três } \\
\text { anos que atinja } 95 \% \text { das mulheres; coletar o exame em } 85 \% \text { das mulheres; conduzir adequadamente os resultados } \\
\text { alterados em } 85 \% \text { das mulheres e ter bom controle de qualidade dos exames e tratamentos. }\end{array}$ \\
\hline
\end{tabular}

Fonte: Elaboração Própria.

Na Figura 2 é possível observar o mapa conceitual referente às recomendações prévias. 
Research, Society and Development, v. 11, n. 1, e45511125096, 2022

(CC BY 4.0) | ISSN 2525-3409 | DOI: http://dx.doi.org/10.33448/rsd-v11i1.25096

Figura 2. Mapa conceitual sobre as recomendações prévias dos documentos compilados. João Pessoa, Paraíba, Brasil. 2018. $(\mathrm{N}=5)$.

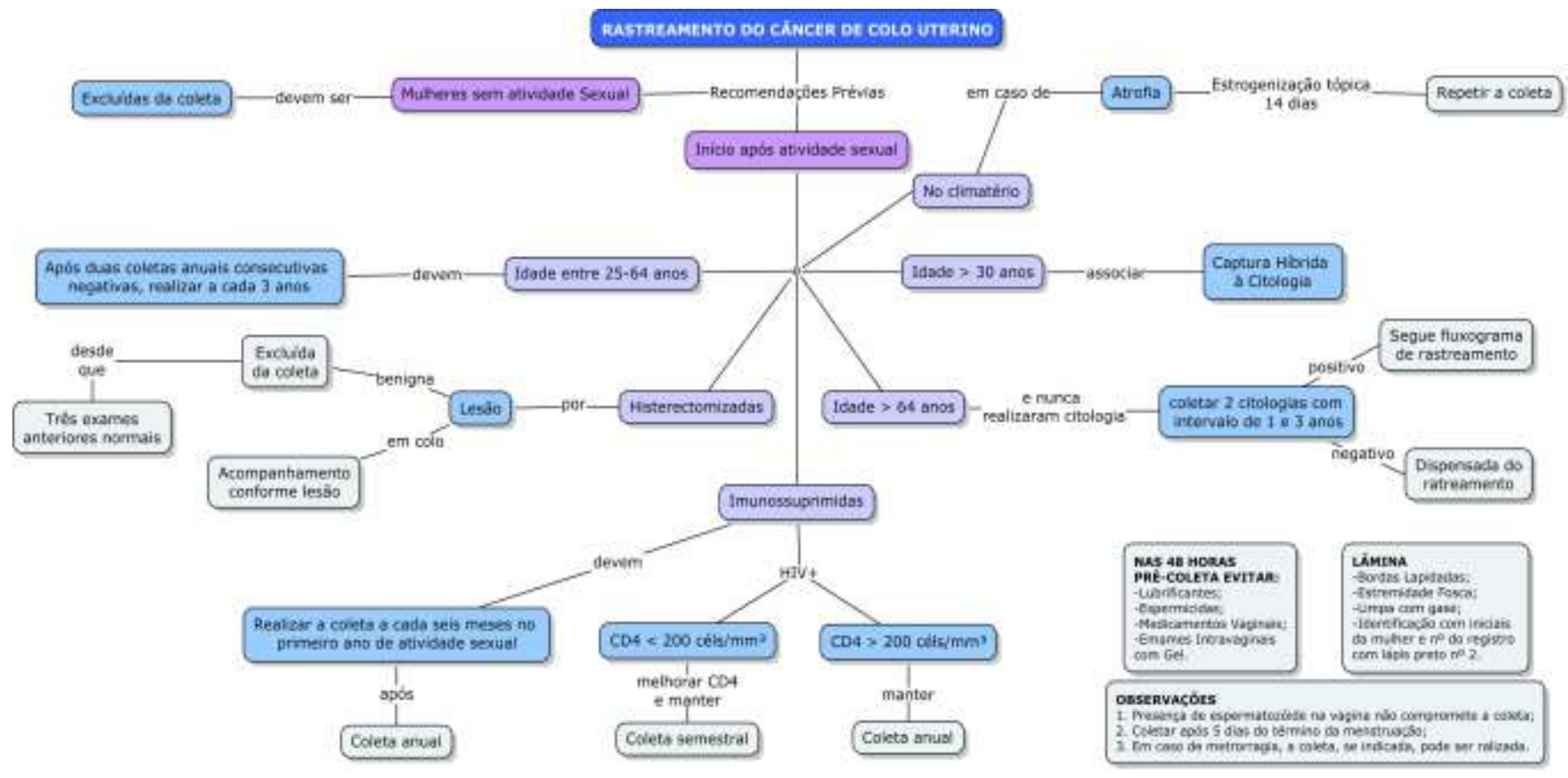

Fonte: Elaboração Própria.

No Quadro 3 encontram-se as recomendações oficiais relacionadas à coleta do material cervical. 
Quadro 3. Informações relacionadas à coleta de material cervical. João Pessoa, Paraíba, Brasil. 2018. (N=2).

\begin{tabular}{|c|c|}
\hline $\begin{array}{c}\text { DOCUMENTO } \\
\text { OFICIAL }\end{array}$ & "INFORMAÇÕES \\
\hline BRASIL (2013) & 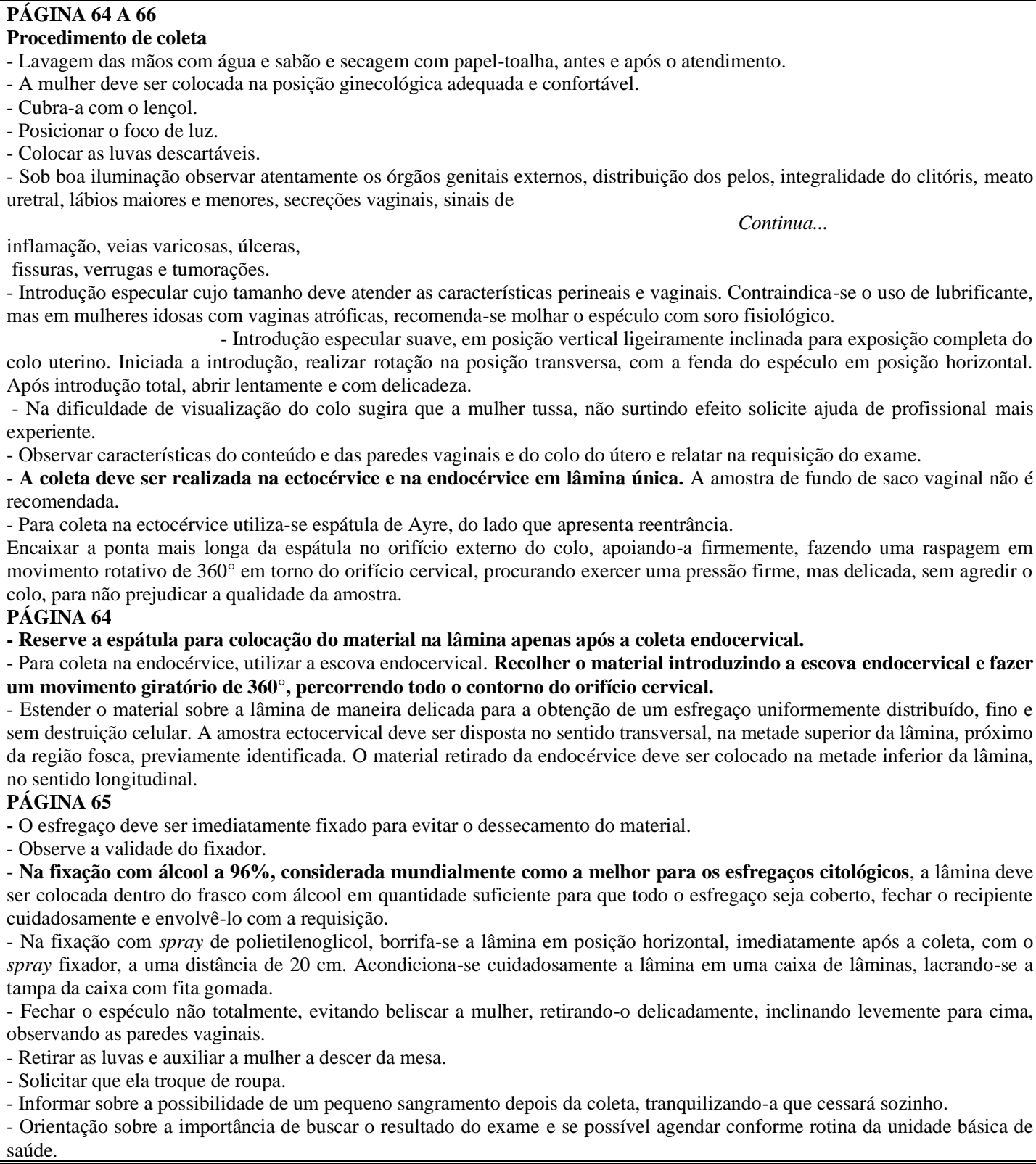 \\
\hline INCA (2016b) & $\begin{array}{l}\text { PÁGINA } 38 \\
\text { - A fixação deve ser realizada de forma rápida e apropriada imediatamente após a coleta, evitando a distorção celular, o } \\
\text { aparecimento de artefatos e a perda da afinidade tintorial. } \\
\text { - As amostras podem ser fixadas com o álcool absoluto, o álcool a } 96 \% \text { por um tempo mínimo de } 15 \text { minutos ou um fixador de } \\
\text { cobertura, como Carbowax, que, ao secar, promove o aparecimento de um fino filme protetor. } \\
\text { - Se a amostra for fixada com álcool, poderá permanecer na solução durante alguns dias. } \\
\text { - Caso seja utilizado fixador de cobertura (spray ou aerossol), a camada de cera protetora deve cobrir a lâmina por completo. } \\
\text { - Esfregaços que forem fixados com esse método devem chegar ao laboratório em, no máximo, } 15 \text { dias. } \\
\text { - Os esfregaços devem ficar totalmente imersos no tubete devidamente fechado, evitando-se à evaporação. } \\
\text { Continua... } \\
\text { - Em situações especiais, o álcool pode ser desprezado para fins de transporte quando encaminhadas imediatamente ao } \\
\text { laboratório. Entretanto, as amostras necessitam de pelo menos } 15 \text { minutos totalmente imersas para a fixação adequada. }\end{array}$ \\
\hline
\end{tabular}

Fonte: Elaboração Própria.

Na Figura 3 é possível observar o mapa conceitual referente às informações para a coleta cervical. 
Figura 3. Mapa conceitual sobre as recomendações para a coleta cervical dos documentos compilados. João Pessoa, Paraíba, Brasil. 2018. $(\mathrm{N}=2)$.

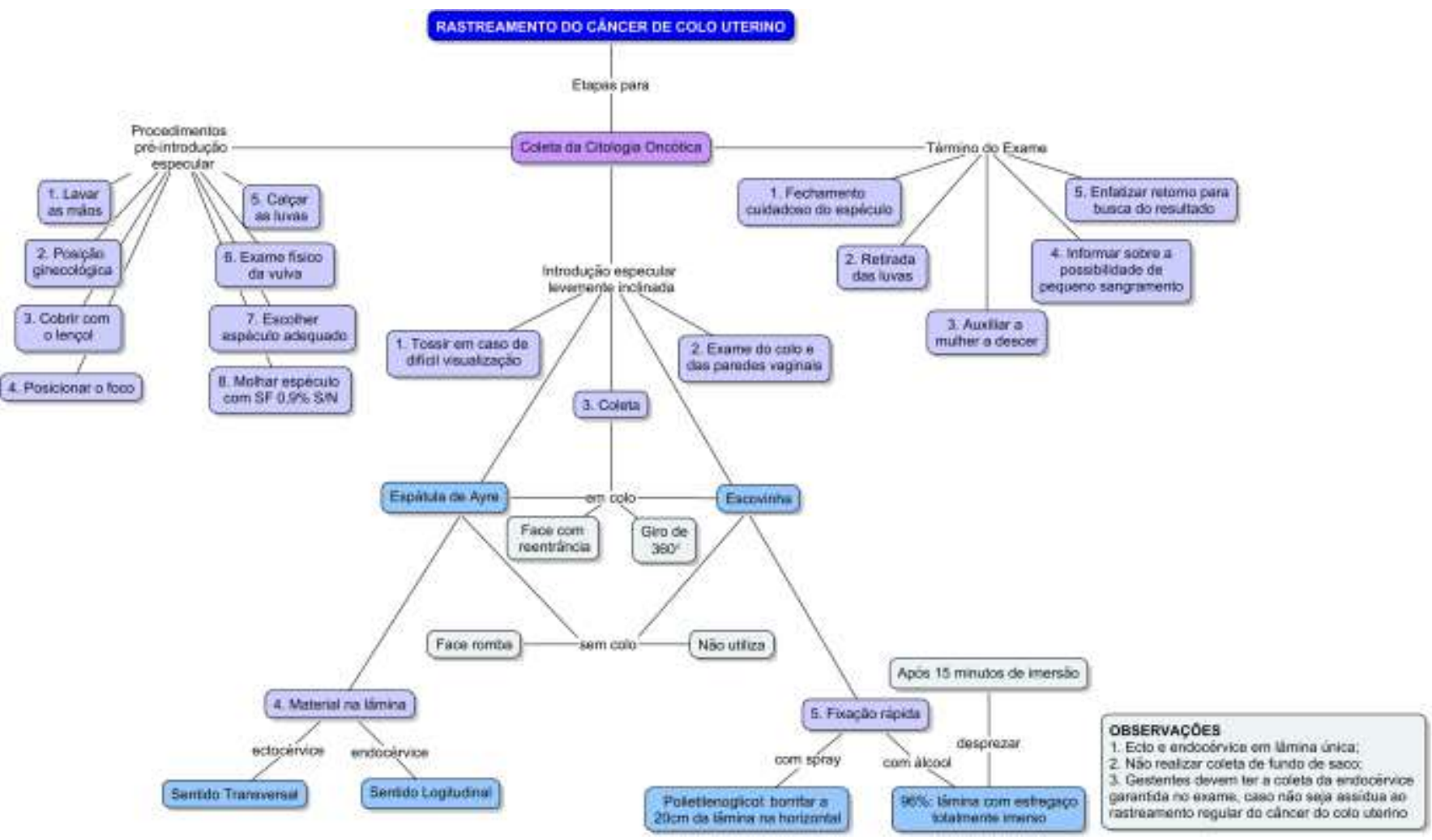

Fonte: Elaboração Própria.

O Quadro 4 traz as recomendações prévias à conduta pós- resultado da citologia oncótica.

Quadro 4. Recomendações prévias relacionadas à conduta pós-resultado da citologia oncótica. João Pessoa, Paraíba, Brasil. 2018. ( $\mathrm{N}=7)$.

\begin{tabular}{||c||l||}
\hline $\begin{array}{c}\text { DOCUMENTO } \\
\text { OFICIAL }\end{array}$ & \multicolumn{1}{c||}{ INFORMAÇÕES } \\
\hline \hline BRASIL (2010) & PÁGINA 71 \\
& - Repetir citologia em 6 meses em casos de atipias de significado indeterminado em células escamosas, provavelmente não- \\
& neoplásicas; Atipias em células escamosas (Lesão intraepitelial de baixo grau). \\
& - Realizar colposcopia em casos de atipias de significado indeterminado, em células escamosas, não podendo afastar alto \\
grau; atipias de significado indeterminado, em células glandulares, provavelmente não- neoplásicas e não podendo afastar \\
alto grau; Atipias de significado indeterminado, em células de origem indefinida, provavelmente não-neoplásicas e não \\
podendo afastar alto grau; Atipias em células escamosas (Lesão intraepitelial de alto grau; \\
alto grau, não podendo afastar microinvasão; carcinoma epidermóide invasor), assim como atipias em células glandulares \\
(adenocarcinoma in situ ou invasor).
\end{tabular}




\begin{tabular}{|c|c|}
\hline & $\begin{array}{l}\text { - Células glandulares (não inclui o epitélio endometrial). } \\
\text { - Células metaplásicas. } \\
\text { Células metaplásicas ou células endocervicais representativas da junção escamocolunar (JEC), constituem-se indicador da } \\
\text { qualidade da coleta. }\end{array}$ \\
\hline INCA (2016b) & $\begin{array}{l}\text { PÁGINA 50 } \\
\text { O esfregaço ideal possui representação dos epitélios escamoso, glandular e/ou metaplásico. No entanto, para considerar um } \\
\text { esfregaço satisfatório, esse deverá conter, obrigatoriamente, células do epitélio escamoso. }\end{array}$ \\
\hline BRASIL (2016b) & $\begin{array}{l}\text { PÁGINA 182 } \\
\text { Amostra insatisfatória para avaliação: } \\
\text { Aquela com leitura prejudicada por natureza técnica ou devido à presença de: sangue, piócitos, artefatos de dessecamento, } \\
\text { contaminantes externos ou intensa superposição celular. } \\
\text { - Nestes casos, a mulher deve repetir o exame em } 6 \text { a } 12 \text { semanas com correção, quando possível, do problema que motivou } \\
\text { o resultado insatisfatório. } \\
\text { Amostra satisfatória para avaliação: } \\
\text { É aquela com células em quantidade representativa, cuja observação permita conclusão diagnóstica. Podem estar presentes } \\
\text { células representativas dos epitélios do colo do útero: células escamosas; células glandulares (não inclui o epitélio } \\
\text { endometrial) e células metaplásicas. } \\
\text { Esfregaços normais somente com células escamosas: } \\
\text { Para garantir boa representação celular do epitélio, o exame deve conter amostra do canal endocervical coletada com escova } \\
\text { e da ectocérvice, coletada com espátula de Ayre. } \\
\text { PÁGINA 183 } \\
\text { Citologia com células endometriais normais fora do período menstrual ou após a menopausa: } \\
\text { - Seguir a rotina de rastreamento citológico. } \\
\text { - Avaliar a cavidade endometrial, confirmando a não realização do exame } \\
\text { próximo ao período menstrual. Avaliação preferencialmente realizada através de } \\
\text { histeroscopia. Na dificuldade de acesso ao método, avaliar o eco endometrial através de ultrassonografia transvaginal. } \\
\text { PÁGINA 184 } \\
\text { - Encaminhar para colposcopia os casos de atipias de significado indeterminado em células escamosas (com exceção das } \\
\text { provavelmente não-neoplásicas), em células glandulares e de origem indefinida. } \\
\text { - Repetir citologia em } 6 \text { meses em casos de atipias de significado indeterminado em células escamosas, provavelmente não- } \\
\text { neoplásica. } \\
\text { - Repetir colposcopia em } 6 \text { meses se lesão intraepitelial de baixo grau. } \\
\text { - Encaminhar para colposcopia os casos de lesão intraepitelial de alto grau; alto grau, não podendo excluir microinvasão; } \\
\text { carcinoma epidermóide invasor, além do adenocarcinoma in situ ou invasor. }\end{array}$ \\
\hline "FEBRASGO (2017) & $\begin{array}{l}\text { PÁGINA } 19 \\
\text { - Os testes de HPV podem ser utilizados para rastreamento do câncer do colo uterino, triagem } \\
\quad \text { com resultado citológico compatível com atipia de células escamosas de significado indeterminado Continua... } \\
\text { (ASC-US) e para seguimento de mulheres tratadas por neoplasia intraepitelial cervical grau } 2 \text { ou } 3 \text { (NIC } 2 / 3 \text { ). Os testes de } \\
\text { HPV são coletados no canal cervical. } \\
\text { - Em mulheres com resultado de citologia sugestiva de ASC-US, um teste de HPV positivo indica a colposcopia. No teste de } \\
\text { HPV negativo, pode-se repetir a citologia em um ano. } \\
\text { - Mulheres tratadas por NIC } 2 \text { ou NIC } 3 \text {, um teste de detecção de HPV com resultado negativo, coletado em seis a } 18 \text { meses, } \\
\text { sugere probabilidade de doença persistente/recidiva próxima de zero. } \\
\text { - Teste de HPV positivo durante o seguimento pós-tratamento, recomenda-se citologia e colposcopia. Não se indica } \\
\text { tratamento complementar frente ao teste de HPV positivo. }\end{array}$ \\
\hline INCA (2016) & $\begin{array}{l}\text { PÁGINA 31 } \\
\text { - Para os resultados de citologia de ASCUS (possivelmente não neoplásico) em pacientes menores de } 25 \text { anos, deve-se } \\
\text { repetir citologia em } 3 \text { anos. Entre } 25 \text { e } 29 \text { anos, deve-se repetir citologia em } 12 \text { meses e nas maiores que } 30 \text { anos, deve-se } \\
\text { repetir em } 6 \text { meses. } \\
\text { - Para os seguintes resultados, as pacientes devem ser encaminhadas para colposcopia: ASCUS (não se pode afastar alto } \\
\text { grau); Células glandulares atípicas de significado indeterminado (AGC); Células atípicas de origem indefinida (AOI); Lesão } \\
\text { de Alto Grau (HSIL); Lesão intraepitelial de alto grau não podendo excluir microinvasão; Carcinoma escamoso invasor; } \\
\text { Adenocarcinoma in situ (AIS) ou invasor. } \\
\text { - Lesão intraepitelial de baixo grau em menores de } 25 \text { anos - deve-se repetir citologia em } 3 \text { anos e em maiores ou igual a } 25 \\
\text { anos - deve-se repetir citologia em } 6 \text { meses. }\end{array}$ \\
\hline
\end{tabular}

Fonte: Elaboração Própria.

Nas Figuras 4 e 5 é possível observar o mapa conceitual referente à conduta profissional frente aos resultados obtidos. 
Research, Society and Development, v. 11, n. 1, e45511125096, 2022

(CC BY 4.0) | ISSN 2525-3409 | DOI: http://dx.doi.org/10.33448/rsd-v11i1.25096

Figura 4. Mapa conceitual sobre as recomendações para a coleta cervical dos documentos compilados. João Pessoa, Paraíba, Brasil. 2018. $(\mathrm{N}=2)$.

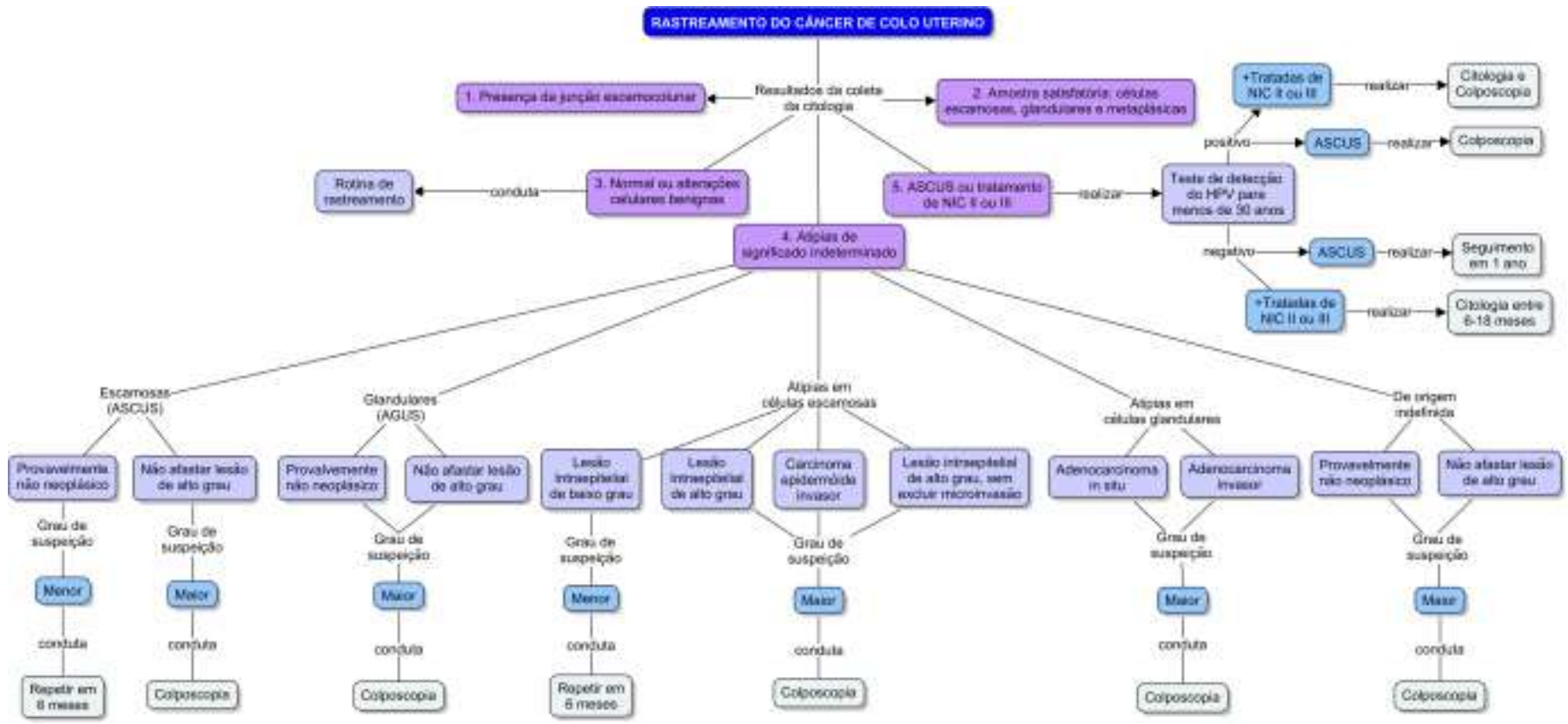

Fonte: Elaboração Própria.

Figura 5. Mapa conceitual sobre as recomendações para a coleta cervical dos documentos compilados. João Pessoa, Paraíba, Brasil. 2018. (N=2).

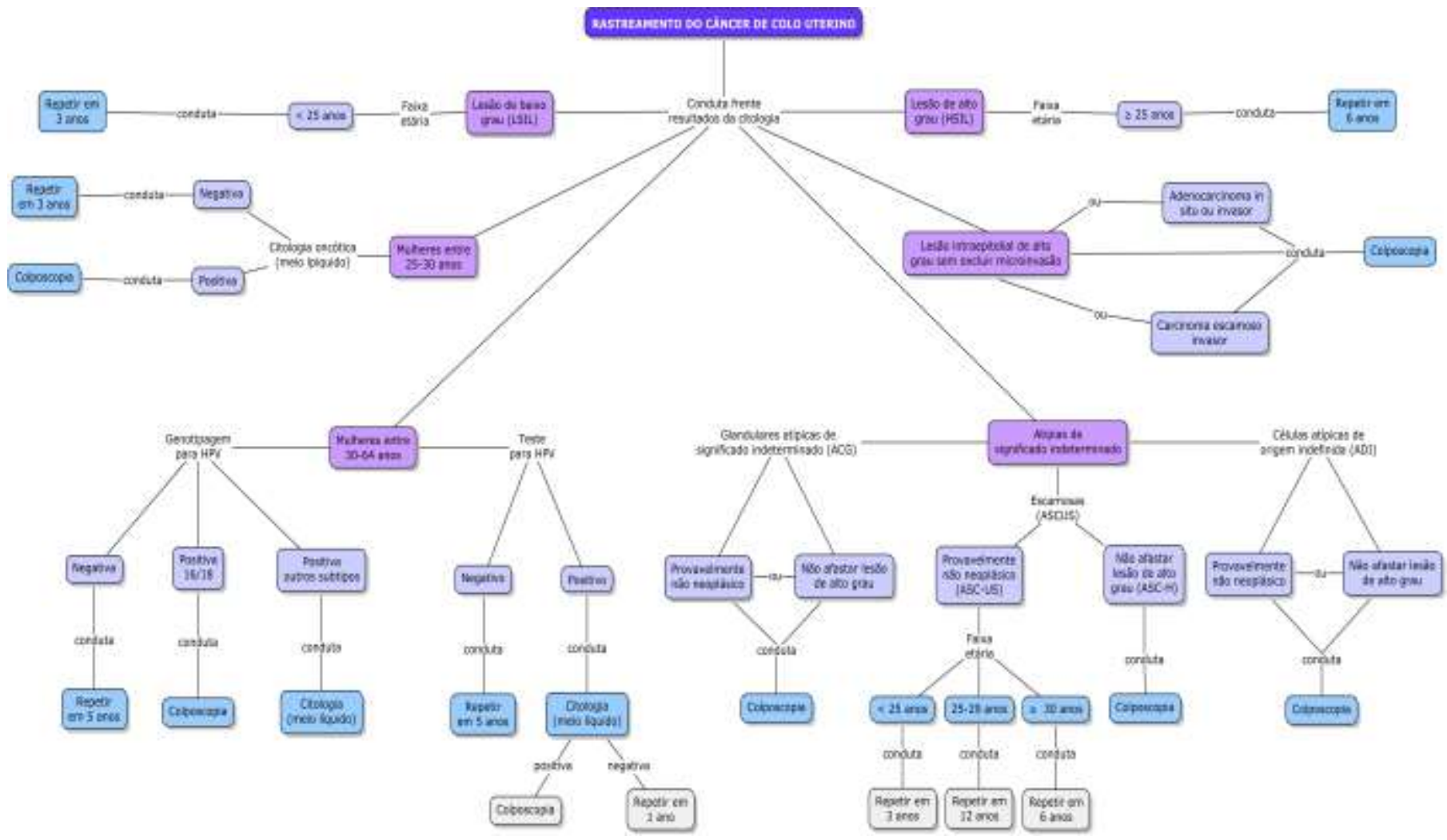

Fonte: Elaboração Própria. 
Após a elaboração preliminar do folheto educativo e refinamento das fases e etapas por meio da revisão dos artigos científicos, houve o envio do protocolo aos juízes para avaliação dos critérios fundamentais. O Quadro 5 apresenta a caracterização dos expertises conforme o Modelo de Fehring adaptado.

Quadro 5. Caracterização dos juízes expertises quanto à idade, ao sexo, à pontuação de Fehring, o tempo de formação e atuação e maior titulação acadêmica. João Pessoa, Paraíba, Brasil, 2019. (N=6).

\begin{tabular}{|c|c|c|c|c|c|}
\hline Juiz & Idade & Gênero & $\begin{array}{c}\text { Pontuação } \\
\text { Fehring }\end{array}$ & Tempo de atuação & Maior titulação \\
\hline 1 & 65 anos & Masculino & 14 & 40 anos & Doutorado \\
\hline 2 & 63 anos & Feminino & 5 & 40 anos & Especialista \\
\hline 3 & 55 anos & Masculino & 14 & 30 anos & Doutorado \\
\hline 4 & 51 anos & Feminino & 11 & 25 anos & Doutorado \\
\hline 5 & 49 anos & Feminino & 12 & 25 anos & Doutorado \\
\hline 6 & 49 anos & Feminino & 8 & 25 anos & Doutorado \\
\hline
\end{tabular}

Fonte: Elaboração Própria.

A escolha dos peritos foi norteada pela experiência na área do estudo. A média de idade entre os juízes foi de 55,3 anos, indo de acordo com Donabedian (1980), quando discorre sobre os fatores que influenciam a qualidade da assistência à saúde, incluindo aqueles relacionados aos recursos humanos como: local da prática assistencial, tempo de formação, capacitação profissional e a experiência de trabalho (tais pessoas são capazes de incorporar conteúdo à estratégia assistencial ao longo dos anos).

Foi incluída uma juíza com pontuação mínima, de acordo com a pontuação de Fehring, porém esta expertise tem larga experiência na área de coleta de citologia oncótica, ocupando o cargo de chefia do setor de ginecologia em hospital universitário, que é referência para diversas especialidades, além de ser docente da disciplina de Ginecologia de uma instituição de ensino superior por um longo período.

Campos e Diniz (2016) ressaltam a importância dos saberes práticos para a formação de profissionais mais qualificados e capacitados para exercerem suas funções e melhor compartilhar o conhecimento aos seus alunos. Concordando com este pensamento, devido à experiência profissional consolidada, a perita foi incluída entre os juízes e prestou valorosa contribuição durante o processo.

Com efeito, pesquisas sobre o perfil de pesquisadores no Brasil mostraram que a maioria é vinculada à universidade, sendo todos doutores e orientadores de mestrado e iniciação científica. As publicações de artigos internacionais respaldam a qualidade das contribuições científica e tecnológica em nosso país (Mendes et al., 2010; Dobriansky et al., 2015). Todavia, cabe ressaltar que a modernidade tem trazido muitas atribuições e obrigações profissionais, retardando a busca das pessoas por maior titulação acadêmica, o que deve ser ponderado diante na riqueza de saberes práticos (Droescher \& Silva, 2014).

Segundo Salvador et al. (2018), estes critérios de Fehring facilitam o processo de validação, pois indicam condições relevantes à escolha de pessoas entendedoras no assunto de interesse, respaldando as sugestões e retirando as fragilidades do conteúdo. De acordo com Almeida et al., (2014) a utilização destes parâmetros tem a pretensão de proporcionar maior aplicabilidade, robustez e veracidade à pesquisa.

Pesquisas de validação em âmbito nacional têm utilizado os critérios de Fehring para fortalecer a tomada de decisão sobre o comitê de juízes (Melo et al., 2011; Silva et al., 2017). Caso ocorresse uma seleção facultativa de pessoas, de acordo com a vontade do pesquisador, talvez as sugestões não tivessem impacto, trazendo vulnerabilidades no produto final.

O folheto educativo foi dividido em 14 questões que foram julgadas segundo critérios de clareza e relevância, individualmente. Estes foram escolhidos, pois julga-se que, para a compreensão de determinado objeto que será utilizado por 
pessoas de diversas formações, deve ser nítido, sem ambiguidades e pertinente para sua prática profissional, sob pena de não ser seguido ou de não ser dada a devida importância à compilação valiosa de diversos manuais institucionais básicos para a boa prática profissional.

Após as correções, foi construído novo questionário, destacando o quesito antigo e o novo, construído considerando as sugestões dos juízes. Foram modificadas as questões com IVC abaixo de 0,80 para relevância ou clareza. Assim, constituiu-se a rodada Delphi II.

Os critérios clareza e relevância foram avaliados pelos juízes e expressos com o IVC para cada critério na rodada Delphi I (Tabela 1).

Tabela 1. Julgamento dos juízes quanto aos critérios clareza e relevância de cada item do instrumento, conforme o Índice de Validade do Conteúdo Individual (IVCI) nas etapas Delphi I e II. João Pessoa, Paraíba, 2020 (N=6).

\begin{tabular}{|c|c|c|c|c|}
\hline \multirow{4}{*}{ Variáveis } & \multicolumn{4}{|c|}{ Rodada } \\
\hline & \multicolumn{2}{|c|}{ Delphi I } & \multicolumn{2}{|c|}{ Delphi II } \\
\hline & Clareza & Relevância & Clareza & Relevância \\
\hline & IVCI & IVCI & IVCI & IVCI \\
\hline Questão 1 & 0,83 & 1 & 1 & 1 \\
\hline Questão 2 & $0,33 *$ & $0,33 *$ & 0,83 & 0,83 \\
\hline Questão 3 & 1 & 1 & 1 & 1 \\
\hline \multirow[t]{2}{*}{ Questão 4} & $0,50^{*}$ & 1 & 1 & 1 \\
\hline & & & & Continua... \\
\hline Questão 5 & $0,50 *$ & 1 & 1 & 1 \\
\hline Questão 6 & 0,83 & 1 & 1 & 1 \\
\hline Questão 7 & 0,83 & 1 & 1 & 1 \\
\hline Questão 8 & $0,66^{*}$ & 0,83 & 1 & 1 \\
\hline Questão 9 & $0,16^{*}$ & $0,33^{*}$ & 0,83 & 1 \\
\hline Questão 10 & $0,16^{*}$ & $0,33^{*}$ & 1 & 1 \\
\hline Questão 11 & $0,16^{*}$ & $0,33^{*}$ & 1 & 1 \\
\hline Questão 12 & $0,16^{*}$ & $0,16^{*}$ & 1 & 1 \\
\hline Questão 13 & $0,16^{*}$ & 0,83 & 1 & 1 \\
\hline Questão 14 & $0,33 *$ & $0,66^{*}$ & 1 & 1 \\
\hline
\end{tabular}

*Valores menores que 0,80. Fonte: Elaboração Própria.

Sobre o posicionamento dos juízes, dos 14 itens avaliados para o critério Clareza, 10 não atingiram o IVC mínimo $(0,80)$ necessário à perpetuação do conteúdo, sendo necessária a modificação dos termos em nível semântico, gramatical, ortográfico ou relacionada às informações equivocadas contidas nos documentos, as quais traziam ambiguidade à tecnologia educativa. Quanto à relevância, menos da metade dos itens, ou seja, apenas seis necessitaram de ajustes para conferir fundamentação ao folheto, considerando a real necessidade de pertencimento daquela informação no material construído. Após as modificações, apenas duas questões para Clareza e uma questão para Relevância não atingiu o valor máximo de IVC, mas estiveram acima do ponto de corte (Tabela 2).

Estudos metodológicos de criação de tecnologia educativa em âmbito nacional e internacional com diversos públicos, quais sejam de crianças escolares, adolescentes, familiares, pacientes, pesquisadores e profissionais de saúde que confirmaram a pertinência do conteúdo, por meio de avaliação de especialistas, têm sido reproduzidos na intenção de fortalecer a produção científica e acadêmica com resultados que sirvam aos setores sociais (Sanderson et al., 2016; Lima et al., 2017; Galindo et al., 2017; Moura et al., 2017).

Sob esta perspectiva, embora as pesquisas supracitadas tenham alcançado na primeira etapa índices de concordância superiores, elas se assemelham a esse estudo porque, apesar de ter necessitado de duas rodadas, o mesmo objetivo foi atingido. 
Medeiros et al., (2015) reforçam que o processo de validação é de essencial importância para dar credibilidade e originalidade aos resultados do trabalho. Virla (2010) ressalta a importância do Alpha de Cronbach na avaliação da consistência interna do instrumento, quando utilizada escala tipo Likert ou outra escala de opções múltiplas no estudo.

Assim, a Tabela 2, exposta a seguir, elenca os valores do Alpha de Cronbach e p-valor obtidos a partir das rodadas Delphi I e II, considerando as variáveis Clareza e Relevância, conforme posicionamento dos juízes.

Tabela 2. Alpha de Cronbach (IC) e p-valor das variáveis Clareza e Relevância nas etapas Delphi I e II conforme julgamento dos juízes. João Pessoa, Paraíba, 2020 (N=6).

\begin{tabular}{lcccc}
\hline \multirow{2}{*}{ Variáveis } & \multicolumn{5}{c}{ Rodada } \\
\cline { 2 - 5 } & Delphi I & Delphi II & p-valor \\
Clareza & Alpha de Cronbach (IC) & p-valor & Alpha de Cronbach (IC) & 0,793 \\
Relevância & $0,792(0,424-0,966)$ & 0,002 & $0,867(0,633-0,978)$ & 0,660 \\
\hline
\end{tabular}

IC $=$ Intervalo de Confiança de 95\%. Fonte: Elaboração Própria.

$\mathrm{Na}$ Tabela 2, a consistência interna dos critérios de clareza e relevância foi avaliada, demonstrando significância estatística na rodada Delphi I $(\mathrm{p} \leq 0,05)$. Na rodada Delphi II, embora o resultado não tenha se mostrado estatisticamente significativo nos dois critérios, as modificações realizadas e as exclusões dos itens permitiram elevar o valor do índice nas duas condições.

O critério de clareza manteve-se na classificação de consistência interna alta, entretanto a relevância dos itens deslocou-se de confiabilidade baixa para um grau alto de confiabilidade, respaldando que a percepção dos juízes foi pertinente quanto à necessidade de manutenção ou não dos itens construídos. Ressalta-se que a importância das alterações no produto tecnológico foi fundamentada pelo aumento quantitativo do IVC e Alpha de Cronbach nas duas ocasiões, indicando que o conteúdo do folheto está apto para as próximas etapas do processo psicométrico de validade do conteúdo (Tabela 2).

Pesquisa de desenvolvimento de protocolo clínico para deteçãa de lesões precursoras do câncer de colo uterino seguiu as mesmas etapas do presente estudo, por meio do levantamento bibliográfico, elaboração do protocolo e validação de conteúdo com o mínimo de concordância de $75 \%$ entre os juízes. No critério clareza, o instrumento superou a concordância mínima após ajustes conforme recomendações para melhoria da efetividade do produto. Os resultados corroboram com este estudo, demonstrando a necessidade dos pesquisadores em utilizar o processo de validade do conteúdo na comunidade científica (Sousa et al., 2018).

Do mesmo modo, estudo metodológico de validação de questionário relacionado ao câncer de mama e colo uterino apontou exclusão de itens após análise estatística. A confiabilidade global averiguada pelo alfa de Cronbach foi de 0,829, revelando alta consistência interna do processo de validade de conteúdo (Lessa et al., 2015). Para enfatizar, todas as questões foram elaboradas tendo como base documentos oficiais do Ministério da Saúde e da Federação Brasileira de Ginecologia e Obstetrícia, entre os anos de 2010 e 2016, tendo sido seguidos fielmente.

Durante a rodada Delphi I, um dos juízes alertou para o fato de que não foi incluído na compilação o material intitulado "Diretrizes Brasileiras para o rastreamento do câncer do colo do útero de 2016" que trouxe a atualização e a correção dos manuais anteriores lançados pelo MS e INCA.

Muitos dos erros encontrados nas questões se deviam ao fato de ter-se seguido os manuais fielmente, tendo sido reproduzidos inclusive seus erros, como podemos evidenciar na questão 13, onde a palavra "anos", seria "meses". "A Diretriz brasileira para o rastreamento do câncer de colo do útero de 2016", que antes não havia sido incluída, foi inserida na rodada Delphi II e veio para sanar estes equívocos, tendo corrigido a maioria das questões com pontuação abaixo do esperado para serem aprovadas. 
As questões 2,4,5,8 a 14 não atingiram IVC mínimo no quesito da clareza, devendo- se, em parte a ausência das diretrizes supracitadas, como também erros de ortografia, como troca de letras em palavras, como na questão 3, onde a palavra "Histerectomizada" foi grafada "Histerectimizadas". Nas questões 4, 5 e 14, por outro lado, foram acrescentadas informações que melhoraram a clareza do quesito, facilitando seu entendimento.

Estudo realizado no Espírito Santo avaliou o perfil epidemiológico de mulheres submetidas à cirugias ginecológicas, verificando dentre outros indicadores, maioria entre 40 a 49 anos, com ensino fundamental incompleto, multíparas (3-5 partos) e vivendo com renda de até um salário mínimo. Dentre as pesquisadas, $43,8 \%$ foram submetidas a histerectomia, destas $29,2 \%$ foram diagnosticadas com mioma uterino e apenas 1,1\% com câncer de colo uterino (Primo et al., 2012).

Embora as pesquisadas estivessem no perfil de risco ao desenvolvimento do câncer, a prevalência de histerectomia foi para doença benigna, sendo que a lesão neoplásica ocupou a última posição. Tão logo o câncer de colo uterino seja a terceira causa de morte por câncer entre mulheres brasileiras, investigações dessa natureza podem endossar a recomendação de não seguimento da coleta citológica em mulheres histerectomizadas, considerando a variação da prevalência da neoplasia em diferentes localidades do país (Primo et al., 2012).

Cardoso et al. (2017), avaliou o perfil de mulheres submetidas à histerectomia e os resultados apontaram que a predominância das indicações de procedimento de histerectomia não estavam diretamente relacionadas a neoplasias uterinas malignas. Além disso, recomendação consistente descontinua a triagem do câncer do colo do útero entre as mulheres submetidas à histerectomia total, pois o exame de Papanicolau entre mulheres que tiveram histerectomias totais por condições benignas é desnecessário, no sentido de onerar o sistema público de saúde, gerando despesas outrora inoportunas (Guo \& Kuo, 2016).

Todavia, existe a possibilidade de alguns profissionais acharem que o exame especular seja necessário para identificar cânceres da vagina ou vulva. É um aspecto subsidiário do procedimento e, em qualquer caso, esses cânceres são muito mais raros que os cânceres do colo do útero, não havendo força de correlação epidemiológica suficiente que sustente o acompanhamento por meio do exame Papanicolau (Miller, 2016). Ainda no folheto, no quesito 4 foram acrescidas informações complementares relacionadas aos casos específicos para realização de exame Papanicolau.

As mulheres imunossuprimidas por ação do Vírus da Imunodeficiência Humana (HIV) apresentam maior chance de desenvolvimento de lesões pré-neoplásicas e neoplásicas do colo uterino, ocasionadas pelo Papilomavírus Humano (HPV), quando comparadas às mulheres soronegativas. Estima-se que a prevalência desse agravo seja três vezes maior nesse públicoalvo, sobretudo, diante da diminuição dos linfócitos T CD4+ e dos níveis mais elevados de carga viral (Guedes et al., 2019), fortalecendo a recomendação de acompanhamento semestral, em vez do seguimento anual para mulheres sem a infecção sexual.

Ainda conforme o autor supracitado, as mulheres com imunossupressão grave e contagem de linfócitos T CD4+ abaixo de 200 células $/ \mathrm{mm}^{3}$ possuem ainda maior risco de desenvolver neoplasia intraepitelial cervical, entretanto o uso da terapia antirretroviral pode fortalecer a resposta imune e vir a ser um fator de proteção, conferindo imunocompetência semelhante às mulheres soronegativas.

Com relação às mulheres imunossuprimidas por ocasião específica de transplantes de rim, coração/pulmão, fígado e pâncreas, evidências mostram um aumento consistente no risco de neoplasia cervical e CC invasivo, demonstrando a importância da vigilância e tratamento em longo prazo. Os relatórios demonstram risco continuado muito tempo após o transplante, enfatizando a necessidade de triagem ao longo da vida de uma mulher. Já no que se refere à imunossupressão por doença autoimune, o risco de neoplasia cervical de alto grau e câncer foi maior entre as mulheres com lúpus eritematoso sistêmico do que aquelas com artrite reumatóide (AR) (Moscicki et al., 2019). 
Deve-se pontuar ainda que a coleta em situações específicas se depara em barreiras diante dos esfregaços atróficos. Após a menopausa, com a redução progressiva dos níveis de estrogênio, a maturação do epitélio escamoso superficial diminui, e o epitélio deixa de produzir células epiteliais superficiais e intermediárias, restando apenas uma fina camada de células parabasais e basais (Backes et al., 2019; Nayar, \& Wilbur, 2015).

A alteração de padrões morfológicos celulares, importantes na identificação de uma lesão, os próprios méritos citológicos tornam-se passíveis de juízo. Tais alterações geram, com frequência, diagnósticos citológicos indefinidos, por simularem lesões pré-malignas, o que requer do profissional experiência e conhecimento para discernir as alterações que se enquadram nos limites das atipias da atrofia (Backes et al., 2019; Nayar \& Wilbur, 2015). Portanto, a estrogenização é recomendada para que a coleta seja realizada novamente após o período de terapia, aumentando as chances de uma leitura satisfatória e fidedigna.

No quesito 5 foram acrescentadas informações, inclusive um novo quadro com significado das palavras, juntamente com as recomendações pré-coleta, trazendo as siglas referentes aos termos utilizados nesta página do folheto. De acordo com Lazarotto (2017), o fluxo menstrual, lubrificantes, gel transdutor de ultrassonografia transvaginal, espermicidas ou medicamentos vaginais são componentes que recobrem os elementos celulares dificultando a avaliação microscópica, prejudicando a qualidade da amostra para o exame citopatológico. Esta informação é parcialmente confirmada pelo estudo desenvolvido por Feit e Mowry (2011) que avaliou o potencial de interferência de lubrificantes comerciais sobre a análise do esfregaço citopatológico.

Ainda segundo Lazarotto (2017), a leitura de uma tecnologia educativa por parte das pacientes, contribui para aquisição de novas informações, contribuindo para que venham a compreender melhor acerca dos riscos aos quais estão expostas, podendo fazer com que se previnam mais adequadamente.

Em estudo desenvolvido por Carvalho e colaboradores (2018), 88\% das mulheres que se submeteram à pesquisa responderam ter realizado o exame preventivo e $12 \%$ não realizaram, tendo em vista que não conheciam os cuidados que antecedem o exame. Foram constatados que os motivos pelos quais as pacientes não se submetem ao Papanicolau são: desconhecimento do câncer, da técnica e da importância do exame; vergonha e constrangimento; valores culturais que dificultam a mudança de atitude. Foram citados ainda terem filhos, emprego e a dificuldade no acesso ao serviço de saúde. Através deste estudo, pode-se concluir que ações educativas poderão auxiliar as mulheres a desmistificar a realização do preventivo, contribuindo para a diminuição da morbidade pelo HPV.

Observando que a falta de conhecimento é um fator preponderante para a não realização do exame, cabe aos profissionais de saúde investir em reflexões sobre suas práticas e a busca de soluções que possam melhorar estrategicamente o atendimento e captação dessas mulheres, envolvendo atividades de educação em saúde para o fortalecimento das ações de prevenção e promoção voltadas ao público feminino (Silva et al., 2019).

Para tanto, estratégias educativas voltadas ao CCU têm sido amplamente divulgadas na literatura. Paula et al. (2016) evidenciou a importância da música na educação em saúde, tendo esta ação educativa contribuído para melhor aceitação e compressão sobre o exame. Paulo Freire foi a base de uma roda de educação em saúde sobre este tema para pacientes em Unidade Básica de Saúde, tendo sido evidenciada boa aceitação através desta abordagem (Valente et al., 2015).

Outras ferramentas tais como jogo educativo com cartas (Tsunechiro et al., 2002), encruzilhadas lúdicas (Maia et al., 2013), material audiovisual (Moreira et al., 2013), cartilha baseada em teorias de autorregulação em saúde (Lima et al., 2017; Peuker et al., 2017), e aplicativos para smartphones (Bilotti et al., 2017). Dessa maneira, o folheto decorrente deste estudo desponta como estratégia respaldada na ciência, sobretudo em diretrizes, configurando-se como caminho relevante à mudança de rumo frente a prevenção e detecção precoce de CCU. 
No quesito 14 foi acrescentado um quadro para esclarecer o significado das siglas e feitas correções de erros presentes nos protocolos. A palavra "anos" foi substituída por "meses". Além da inserção de informações que inerem às condutas referentes a diferentes atipias de significado indeterminado.

A categoria ASC-US abrange alterações morfológicas insuficientes para definir uma lesão intraepitelial, e amostras com aumento difuso dos núcleos, presença de alterações reparativas, degenerativas, dessecamento e padrão atrófico podem ser de difícil interpretação entre negativo para lesão intraepitelial e malignidade e ASC-US. Em casos de ASC-US com seguimento histológico, os resultados variam de benigno a câncer (Rosendo et al., 2018).

Estudos associam o tamanho da lesão e limitações da amostra como as principais causas de citologias de ASC-US com lesões graves subjacentes detectadas na histologia (Morais et al., 2011; Galão et al., 2012; López-Alegría et al., 2015). No Brasil, as condutas para ASC-US começaram a ser discutidas a partir de 2002 em encontros entre especialistas da área promovidos pelo Ministério da Saúde e Instituto Nacional do Câncer. Desde então, tem sido feitas atualizações e concluiu-se que em mulheres com menos de 30 anos a chance de malignização é baixa, o que justifica o maior intervalo de tempo entre as coletas de citologia (Abaixo de 25 anos, re-coleta em 3 anos e entre 25 e 29 anos, coletar novamente após 1 ano). Difere da conduta acima de 30 anos, que é a repetição do exame em 6 meses, tendo sido corroborado pelo estudo de Rosendo et al. (2018), que concluiu a importância do seguimento de ASC-US em mulheres acima de 30 anos.

Estudo desenvolvido por Oliveira e colaboradores (2018), constatou que nenhuma conduta foi adotada em 36,97\% de citologias do tipo ASC-US. O tempo de realização de uma nova citologia para resultado do tipo ASC-US em mulheres com mais de 30 anos de idade foi de 13,03 meses, também em desacordo com as diretrizes. Os autores sugerem que mesmo para uma população de mulheres brasileiras atendidas em clínicas privadas, as recomendações das diretrizes clínicas nacionais para resultados citológicos apresentando ASC's não são seguidas, comprometendo a qualidade da detecção e tomada de decisão positiva frente à uma possibilidade de lesão.

Com relação às atipias glandulares de significado indeterminado, Marques et al (2011) refere que a classificação do Sistema de Bethesda (1988) incluiu os diagnósticos relacionados às células glandulares atípicas na classificação do exame citológico do colo do útero. Desde então, tem-se valorizado a presença e a avaliação das células endocervicais nos esfregaços citológicos. A citologia cervicovaginal com ACG permite selecionar as mulheres que deverão ter seguimento imediato com colposcopia e posterior avaliação histológica, para que seja instalada uma conduta terapêutica adequada visando à redução das taxas de câncer cervical.

Os quesitos a seguir foram excluídos pois faziam referência ao teste de HPV , que foi sugerido nos protocolos da FEBRASGO, porém, não tiveram respaldo pelo Ministério da Saúde. O teste de HPV consiste na identificação da presença do DNA de diferentes subtipos de HPV no colo uterino (Apgar et al., 2010).

A construção deste folheto educativo tem o intuito de orientar profissionais de saúde, que, em sua maioria, trabalham na atenção primária, em unidades de saúde da família, que seguem as orientações do Ministério da Saúde. Portanto, os itens foram excluídos, após a sugestão da maioria dos juízes, com IVCs abaixo do esperado quanto a clareza e relevância.

O quesito 2 faz referência ao teste de HPV cujas informações mostram um fluxograma de rastreio do câncer do colo do útero como base em estratificação etária. Pesquisa metodológica sobre validação de tecnologia educativa voltada a vacina contra o papilomavírus humano utilizou o Índice de Validade de Conteúdo e para o público alvo considerou-se a proporção de concordância. Os resultados apresentaram IVC global de 0,95, indicando ótimo grau de concordância entre os juízes sobre esta informação enquanto estratégia preventiva ao câncer de colo uterino (Cruz et al., 2019). Cabe ressaltar que investigações metodológicas sobre a vacina contra o HPV é menos escassa que aqueles que indicam captura híbrida.

Para tanto, no presente estudo as informações relacionadas ao HPV diziam respeito à captura híbrida, que é um teste diagnóstico em casos alterados de citologia oncótica. Estas informações foram excluídas, pois se ponderaram os resultados do 
IVC neste item, juntamente com as recomendações dos peritos, considerando que o sistema público não oferece este serviço gratuito à população. Logo, essa decisão foi importante para aumentar a aceitabilidade do instrumento educativo e melhorar a adesão dos profissionais ao folheto por meio da realidade de saúde ofertada pelos órgãos governamentais.

A relevância em associar o método captura híbrida para investigar a presença de DNA de HPV de alto risco à citologia parte de seu alto valor preditivo negativo para lesões intraepiteliais escamosas de baixo grau e, principalmente, para lesões intraepiteliais escamosas de alto grau. Isso pode ajudar a definir o acompanhamento das pacientes com células escamosas atípicas (Adorno et al., 2020).

Sobre isso, Serour e colaboradores (2017), afirmaram por meio de estudo prospectivo que o uso do teste de captura híbrida é uma estratégia confiável para identificar mulheres com alto risco de câncer do colo do útero, devendo ser ofertado para dirimir equívocos histopatológicos.

Um alto valor preditivo negativo atribuído à captura híbrida após a identificação de células escamosas atípicas na colpocitologia pode ajudar na definição de condutas subsequentes, na medida em que tranquiliza o médico e o paciente e permite a redução da frequência de procedimentos invasivos, como colposcopia e biópsia (Adorno et al., 2020).

O quesito 12 faz referência ao teste de HPV, com informações que fazem referência ao fluxograma para ASCUS ou tratamento de NIC II ou III. Para acompanhamento de mulheres com diagnóstico de ASC, vêm sendo utilizados testes de biologia molecular para detecção do DNA-HPV através dos métodos de captura híbrida e reação em cadeia da polimerase (PCR) vinculados ao exame citopatológico. Estudo-mostra que cerca de 55\% de mulheres com ASC apresentam resultados positivos para HPV, e cerca de $10 \%$ a $20 \%$ das mulheres com HPV positivo tinham lesão pré-câncer ou câncer (Feijó \& Cavagnolli, 2018).

O diagnóstico citológico de células escamosas atípicas de significado indeterminado (ASC-US) não significa, na maioria dos casos, a presença de lesão precursora ou câncer. No entanto, a identificação das mulheres com esse diagnóstico incrementa a probabilidade de ter uma dessas lesões, justificando o encaminhamento colposcópico. Desse modo, mulheres com citologia ASC-US podem realizar o teste de HPV-DNA alternativamente a um novo teste de citologia. Se o teste for positivo para tipos oncogênicos, a mulher deve ser encaminhada para colposcopia (Zeferino et al., 2018).

Estudo de acompanhamento de longo prazo indica que as mulheres tratadas com NIC II / III têm maior risco de desenvolver câncer de colo do útero por pelo menos 10 anos e talvez até 20 anos após o tratamento, quando comparadas à população geral. $\mathrm{O}$ acompanhamento ideal para a detecção de doença residual ou recorrente parece ser uma citologia associada à colposcopia, mas os dados atuais sugerem que o teste de HPV-DNA identifica a doença mais cedo, com maior sensibilidade e especificidade, do que o acompanhamento da citologia (Zeferino et al., 2018).

Portanto, torna-se oportuno enfatizar que a informação do teste de captura híbrida pode ser incluída como um componente relevante artifício em futuras atualizações de manuais e diretrizes para que profissionais possam educar as usuárias do serviço de saúde, oferecendo como recurso adicional uma nova ferramenta diagnóstica às mulheres que tenham acesso a serviços privados de saúde, ou então, que seja um elemento incluído no serviço público em longo prazo, considerando os valores monetários imbricados ao exame.

Os quesitos 10 e 11 também foram excluídos por já terem sido citados em outra parte do folheto de forma mais simples e compreensível, tornando-se então, repetitivos, conforme julgamento dos juízes.

O Quadro 6 retoma de maneira sucinta, os itens inclusos na rodada Delphi I e suas modificações/exclusões pós julgamento dos juízes na rodada Delphi II. As retificações e exclusões subsidiaram um ICV adequado (superior a 0,80) em todos os quesitos. 
Quadro 6. Representação dos itens substituídos ou excluídos conforme julgamento dos juízes.

\begin{tabular}{|c|c|c|}
\hline \multicolumn{2}{|l|}{ Quesitos Antigos } & \multirow{2}{*}{$\begin{array}{l}\text { Quesitos Atuais } \\
\text { Rodada Delphi II - Pós correção dos Juízes } \\
\text { • } 1 \text { "Mulheres que não iniciaram vida sexual" } \\
\text { • } 2 \text { "Idade entre 25- } 64 \text { anos (tendo iniciado atividade } \\
\text { sexual)" }\end{array}$} \\
\hline 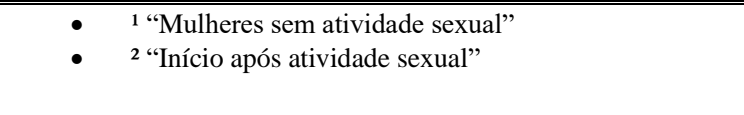 & Questão 1 & \\
\hline $\begin{array}{l}\text { - } \quad \text { quesito aborda aspectos inerentes ao diagnóstico } \\
\text { do HPV conforme estratificação etária. }\end{array}$ & Questão 2 & $\begin{array}{l}\text { - } \mathrm{O} \text { quesito foi excluído do folheto por ter sido } \\
\text { considerado não adequado pela maioria dos juízes. }\end{array}$ \\
\hline • "Três exames" & Questão 3 & "Dois exames" \\
\hline $\begin{array}{c}\bullet \quad 1 \text { "Devem" } \\
\bullet \quad 2 \text { "Coleta anual" } \\
\text { Na linha HIV - CD4 < } 200 \text { céls } / \mathrm{mm}^{3} \\
\bullet \quad 3 \text { "Coleta anual" } \\
\text { Na linha HIV - CD4> } 200 \text { céls } / \mathrm{mm}^{3} \\
\bullet \quad 4 \text { "Manter" e "Coleta anual" }\end{array}$ & Questão 4 & $\begin{array}{l}\bullet \quad 1 \text { "Outras imunossupressões" } \\
\qquad \quad 2 \text { "Duas citologias normais? - sim - coleta } \\
\text { anual e - não- colposcopia" } \\
\text { Na linha HIV - CD4 < } 200 \text { céls } / \mathrm{mm}^{3} \\
\bullet \quad 3 \text { "Citologia e Colposcopia semestral" } \\
\text { Na linha HIV - CD4> } 200 \text { céls } / \mathrm{mm}^{3} \\
\bullet \quad 4 \text { "Duas citologias normais? - sim - coleta anual e - } \\
\quad \text { não- colposcopia" }\end{array}$ \\
\hline $\begin{array}{l}\bullet \\
\text { Quadro da esquerda } \\
\bullet \quad 2- \\
\text { Quadro azul à direita } \\
\bullet \quad \text { "Siglas sem seu respectivo significado } \\
\text { Quadro laranja à esquerda } \\
\qquad \quad 4 \text { "Medicamentos vaginais" e "Exames intravaginais } \\
\quad \text { com gel" }\end{array}$ & Questão 5 & $\begin{array}{l}\bullet \quad 1 \text { "Indicada" } \\
\text { Quadro da esquerda } \\
\bullet \quad 2 \text { Adicionadas ao quadro da esquerda as expressões } \\
\text { "exame intravaginal com gel e relação sexual" } \\
\text { Quadro azul à direita } \\
\bullet \quad 3 \text { Acrescido a sigla seu respectivo significado } \\
\text { Quadro laranja à esquerda } \\
\quad 4 \text { "Limpar com gaze seca" e identificação } \\
\text { com iniciais da mulher em letra de forma e número } \\
\text { do registro com lápis preto n }{ }^{\circ} \text { " } \\
\end{array}$ \\
\hline $\begin{array}{ll} & 1 \text { "Procedimentos pré-introdução especular" } \\
\text { • } & 2 \text { "de Colo de Uteniro" } \\
\end{array}$ & Questão 6 & $\begin{array}{ll} & 1 \text { "Procedimentos prévios à introdução especular" } \\
\bullet & 2 \text { "De Colo Uterino" } \\
\end{array}$ \\
\hline 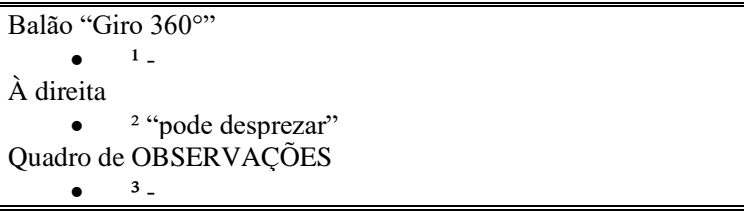 & Questão 7 & 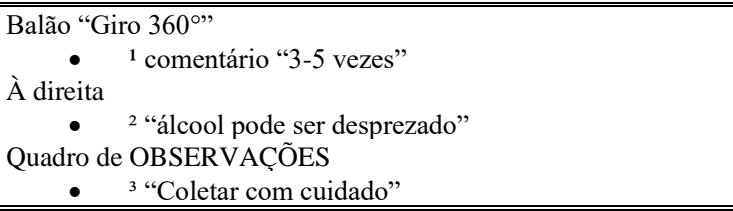 \\
\hline • $\quad$ "Presença de junção escamocolunar" & Questão 8 & $\bullet \quad$ "Amostra insatisfatória" \\
\hline $\begin{array}{lllll}\text { - } & \begin{array}{l}\text { Quesito abordando } \\
\text { indeterminado }\end{array} & \text { atipias de } & \text { significado } \\
\end{array}$ & Q Questão 9 & - $\quad$ Quesito abordando diferentes condições histológicas \\
\hline - $\quad$ Quesito apontando atipias em células escamosas & Questão 10 & $\begin{array}{l}\text { - Quesito retirado do folheto por ser considerado } \\
\text { repetitivo e pouco claro }\end{array}$ \\
\hline - Quesito apontando atipias em células glandulares & Questão 11 & $\begin{array}{l}\text { - Quesito retirado do folheto por ser considerado } \\
\text { repetitivo e pouco claro }\end{array}$ \\
\hline $\begin{array}{ll}- & \text { Quesito abordando ASCUS e tratamento de NIC II } \\
\text { ou III }\end{array}$ & Questão 12 & $\begin{array}{l}\text { Quesito retirado do folheto por ter sido considerado } \\
\text { pouco relevante }\end{array}$ \\
\hline $\begin{array}{l}\text { Faixa etária de Lesão intraepitelial de baixo grau } \\
\text { • } 1 \text { - } \\
\text { Faixa etária de Lesão intraepitelial de alto grau } \\
\qquad \quad 2 \text { "Maior ou igual" } \\
\text { • } 3 \text { "Repetir em } 6 \text { anos" }\end{array}$ & Questão 13 & $\begin{array}{l}\text { Faixa etária de Lesão intraepitelial de baixo grau } \\
\text { • } 1 \text { "Maior de } 25 \text { anos" - conduta- Repetir citologia em } \\
\text { Faixa etária de Lesão intraepitelial de alto grau } \\
\text { • } \quad 2 \text { "qualquer idade" } \\
\text { • } \quad 3 \text { "Colposcopia" } \\
\end{array}$ \\
\hline $\begin{array}{c}\text { Coluna ASCUS - provavelmente não neoplásico } \\
\text { • } 1 \text { "Repetir em } 12 \text { anos" } \\
\text { • } 2 \text { "Repetir em } 6 \text { anos" } \\
\end{array}$ & Questão 14 & $\begin{array}{l}\text { Coluna ASCUS - provavelmente não neoplásico } \\
\bullet \quad 1 \text { "Repetir em } 12 \text { meses" } \\
\bullet \quad 2 \text { "Repetir em } 6 \text { meses" } \\
\end{array}$ \\
\hline
\end{tabular}

Fonte: Elaboração própria.

\section{Conclusão}

Na perspesctiva de assistência que inere à saúde da mulher, esta pesquisa trás visibilidade a uma temática considerada amplamente discutida, todavia, ainda carece de distintas abordagens para suprir suas reais necessidades.

Quanto ao IVC, na rodada Delphi I, quanto a clareza, dez entre as 14 questões não obtiveram pontuação mínima de 0,80 e quanto a relevância, foram aprovadas oito. Na etapa Delphi II, todos os itens foram aprovados quanto a clareza e relevância, tendo sido concluída a etapa que este trabalho se propôs. Quanto ao Alpha de Cronbach, a consistência interna dos 
critérios de clareza e relevância foi avaliada, demonstrando significância estatística na rodada Delphi I ( $\leq 00,05)$. Na rodada Delphi II, embora o resultado não tenha se mostrado estatisticamente significativo nos dois critérios, as modificações realizadas e as exclusões dos itens permitiram elevar o valor do índice nas duas condições.

O resumo de protocolos oficiais, seguido da sua compilação na forma de folheto educativo contribui para a fácil disseminação do conhecimento a cerca das técnicas de coleta de citologia oncótica, norteando o profissional de saúde sobre as peculiaridades da pré-coleta, destacando passos para preparação do exame; destacando a técnica correta de coleta e orientações iniciais diante dos resultados apresentados.

A elaboração de uma ferramenta educativa destinada aos profissionais de saúde tem como objetivo modificar a morbidade da região em que for utilizada. O norteamento dos profissionais que trabalham com citologia oncótica, destacando a correta técnica de coleta, assim como a tomada de decisão frente aos resultados fazem parte do propósito maior de melhorar a qualidade de vida das pessoas.

Todavia, devido a constante elaboração de protocolos atualizados de resultados de exames, tanto de nomenclatura de citologia, quanto de análise dos seus resultados, este trabalho torna-se limitado a médio e longo prazo. Ademais, podem haver modificações e adaptações também nas técnicas já consagradas de coleta de citologia oncótica, a fim de otimizar seus resultados, cujo folheto pode acompanhar a evolução literária. À luz dos estudos ainda futuros, este trabalho poderá ser continuado e reformulado, conforme as características psicométricas de estudos metodológicos, conservando seu formato e objetivos principais, de modo que possa atender às novas recomendações de maneira fácil, prática e rápida.

\section{Referências}

Adorno, F. A., Lousada, D. C. F., Coelho, K. M., \& França, P. H. C. (2020). A utilidade da captura híbrida para o HPV de alto risco em pacientes com atipia de células escamosas na colpocitologia. J. Bras. Patol. Med. Lab, 56, 1-6. https://doi.org/10.5935/1676-2444.20200006

Almeida, M. A., Seganfredo, D. H., Barreto, L. N. M., \& Lucena, A. F. (2014) Validação de indicadores da Nursing Outcomes Classification para adultos hospitalizados em risco de infecção. Texto \& Contexto Enferm. Florianópolis - SC. 23(2), 309-317. https://doi.org/10.1590/0104-07072014003330012

Apgar, B. S., Botzman, G. L., \& Spitze, M. (2010). Colposcopia: princípios e práticas. (2a ed.), Revinter

Backes, L. T. H., Mezzomo, L. C. Buffon, A., \& Calil, L. N. (2019). Análise citomorfológica de esfregaços citológicos cervicais de mulheres com idade superior a 60 anos. J. Bras. Patol. Med. Lab, 55(2), 136-147. https://doi.org/10.5935/1676-2444.20190016

Bilotti, C. C., Nepomuceno, L. D., Altizani, G. M., da Silva Macuch, R., Lucena, T. F. R., Bortolozzi, F., \& Bernuci, M. P. (2017). M-Health no controle do câncer de colo do útero: pré-requisitos para o desenvolvimento de um aplicativo para smartphones. Rev Eletron Comum Inf Inov Saúde, 11(2). https://doi.org/10.29397/reciis.v11i2.1217

Brasil. Ministério da Saúde (BR). (2016). Protocolo da atenção básica a saúde da mulher. http://189.28.128.100/dab/docs/portaldab/ publicacoes/protocolo_saude_mulher.pdf.

Brasil. Ministério da Saúde (BR). (2013). Controle dos cânceres do colo do útero e da mama. (2a ed.), Cadernos de Atenção Básica, n. 13. http://bvsms.saude.gov.br/bvs/publicacoes/controle_canceres_colo_utero_2013.pdf.

Brasil. Ministério da Saúde (BR). (2010). Rastreamento. Brasília. Série A. Normas e Manuais Técnicos. Cadernos de Atenção Primária, n. 29

Campos, L. M. L., \& da Silva Diniz, R. E. (2016). A prática como fonte de aprendizagem e o saber da experiência: o que dizem professores de Ciências e de Biologia. Investigações em Ensino de Ciências, 6(1), 79-96. https://www.if.ufrgs.br/cref/ojs/index.php/ienci/article/view/587

Cardoso, B. C., Camargo, C. R., \& Fernandes, I. (2017). Perfil de Mulheres Submetidas a Histerectomia e influência da deambulação na alta hospitalar. Rev Pleiade, 11(21), 17-24. https://pleiade.uniamerica.br/index.php/pleiade/ article/view/330.

Carreira, A. (2017). O sistema Bethesda para relatar diagnósticos citológicos cervicais/vaginais. Internat Journ Gynecol Pathol. 10(4), 323-325. https://pathologika.com/citologia/citologia-cervico-vaginal/sistema-de-bethesda.

Carvalho, F. O., Altino, K. K. M., \& da Silva Andrade, E. G. (2018). Motivos que influenciam a não realização do exame de Papanicolau segundo a percepção de mulheres. Rev Inic Científica e Extensão, 1(Esp 5), 416-424. https://revistasfacesa.senaaires.com.br/index.php/iniciacao-cientifica/article/view/108.

Cruz, G. D. C. V.; Vasconcelos, M. G. F.; Maniva, S. J. C. D. F., \& Carvalho, R. E. F. L. D. (2019). Construção e validação de tecnologia educacional em vacina contra papilomavírus humano para adolescentes. Esc. Anna Nery, 23(3). https://doi.org/10.1590/2177-9465-EAN-2019-0050

Donabedian, A. (1980). Quality assessment and monitoring: retrospect and prospect. Evaluation \& the health professions, 6(3), 363-375 
Dobrianskyj, W. L. N.; Leite, C. R.; Stasiak, G. R. S.; Santos, C. A., \& Forteski, R. (2015). O estresse no trabalho do professor. Imagens da Educação. Paraná. 5(3), 40-52. https://doi.org/10.4025/imagenseduc.v5i3.25789

Droescher, F. D., \& Silva, E. L. (2014). O pesquisador e a produção científica. Perspectivas em Ciência da Informação. Belo Horizonte - MG. 19(1), 170-189. https://doi.org/10.1590/S1413-99362014000100011

Febrasgo - Federação Brasileira das Associações de Ginecologia e Obstetrícia. (2010). Manual de orientação trato genital inferior. https://www.febrasgo.org.br/images/arquivos/manuais/ManualdePatologiadoTratoGenitalInferior/ Manual-PTGI-Cap-01-Colposcopia.pdf.

Febrasgo - Federação Brasileira das Associações de Ginecologia e Obstetrícia. (2017). Rastreio, diagnóstico e tratamento do câncer de colo de útero. 2017. https://www.febrasgo.org.br/media/k2/attachments/05z-zdiagnoysticozrastrei ozeztratamentozdozcayncerzdezcolozdezuytero.pdf.

Feijó, J. K. \& Cavagnol, G. (2018). Prevalência de atipias de significado indeterminado e sua relação com o papilomavírus em uma população de Caxias do Sul. $R B A C, 50(2), 144-148$

Fehring, R. J. (1987). Methods to validate nursing diagnoses. Nursing Faculty Research and Publications, 16(6), 625-629. https://epublications.marquette.edu/cgi/viewcontent.cgi?article=1026\&context=nursing_fac.

Feit, T. D. \& Mowry, D. A. (2011). Interference potential of personal lubricants and vaginal medications on ThinPrep® pap tests. $J$ Am Board Fam Med, 24(2), 181-186. https://doi.org/10.3122/jabfm.2011.02.100086

Galindo, N. M., Caetano, J. A., Barros, L. M., Silva, T. M., \& Vasconcelos, E. M. R. (2017). Primeiros socorros na escola: construção e validação de cartilha educativa para professores. Acta Paul Enferm. São Paulo/SP. 30(1), 87-93. https://doi.org /10.1590/1982-0194201700013.

Guo, F., \& Kuo, Y. F. (2016). Roles of health care providers and patients in initiation of unnecessary Papanicolaou testing after total hysterectomy. Am $J$ Public Health, 106(11), 2005-2011. https://ajph.aphapublications.org/doi/full/ 10.2105/AJPH.2016.303360.

Hyrkäs, K., Appelqvist-Schmidlechner, K., \& Oksa, L. (2003). Validating an instrument for clinical supervision using an expert panel. Int J Nurs Stud, 40(6), 619-625. https://doi.org/10.1016/S0020-7489(03)00036-1

Inca - Instituto Nacional do Câncer José Alencar Gomes da Silva. (2016a) Tipos de câncer: colo do útero. http://www2.inca.gov.br/ $\mathrm{wps} / \mathrm{wcm} / \mathrm{connect/tiposdecancer/site/home/colo \_ utero.}$

Inca - Instituto Nacional do Câncer José Alencar Gomes da Silva. (2016b). Detecção precoce de câncer de colo de útero. http://www2.inca.gov.br/wps/wcm/connect/tiposdecancer/site/home/ colo_utero/deteccao_precoce.

Inca - Instituto Nacional do Câncer José Alencar Gomes da Silva. (2016c). Diretrizes brasileiras para o rastreamento do câncer do colo do útero. (2a ed.), https://www.inca.gov.br/publicacoes/livros/diretrizes-brasileiras-para-o-rastreamento-do-cancer-do-colo-do-utero.

Inca - Instituto Nacional do Câncer José Alencar Gomes da Silva. (2016d). Manual de Gestão e Qualidade para Laboratório de Citopatologia. (2a ed.) https://www.inca.gov.br/publicacoes/manuais/manual-de-gestao-da-qualidade-para-laboratorio-de-citopatologia.

Inca - Instituto Nacional do Câncer José Alencar Gomes da Silva. (2018). Incidência de Câncer no Brasil. http://www1.inca.gov.br/ estimativa/2018/introducao.asp.

Inca - Instituto Nacional do Câncer José Alencar Gomes da Silva. (2020). Câncer de colo de útero. https://www.inca.gov.br/sites /ufu.sti.inca.local/files/media/document/estimativa-2020-incidencia-de-cancer-no-brasil.pdf.

Lazarotto, V. (2017). Efetividade de uma tecnologia educativa na promoção da saúde feminina. 68f. Trabalho de Conclusão de Curso (Graduação em Enfermagem) - Universidade Federal de Mato Grosso, Instituto de Ciências da Saúde, Sinop. http://bdm.ufmt.be/handle/1/963.

Lessa, P. R. A., Ribeiro, S. G., Aquino, P. D. S., Almeida, P. C. D., \& Pinheiro, A. K. B. (2015). Validation of the Adherence Determinants Questionnaire scale among women with breast and cervical cancer. Rev. Latino-Am Enfermagem, 23(5), 971-978. https://doi.org/10.1590/0104-1169.0222.2638

Lima, M. B. D., Rebouças, C. B. D. A., Castro, R. C. M. B., Cipriano, M. A. B., Cardoso, M. V. L. M. L., \& Almeida, P. C. D. (2017). Construction and validation of educational video for the guidance of parents of children regarding clean intermittent catheterization. Rev Esc Enferm USP, 51. https://doi.org/10.1590/S1980-220X2016005603273

López-Alegría, F., Poblete, O. Q., Lorenzi, D. S. D., \& Oyanedel, J. C. S. (2015). Clinical management of the first ASCUS report in Chile. Prospective singlecohort study. São Paulo Med J., 133(6), 480-487. https://doi.org/10.1590/1516-3180.2014.9142511

Maia, T., Machado, G. D. O. C., dos Santos, E. S. J., Verjovsky, M., Villela, C., \& Jurberg, C. (2013). "Encruzilhadas. O Jogo da sua Vida": Desenvolvimento de Instrumento Lúdico na Prevenção ao Câncer. Rev Bras Cancerologia, 59(2), 219-227. https://rbc.inca.gov.br/revista/index.php /revista/article/view/527.

Munaretto, L. F., Corrêa, H.L., \& da Cunha, J. A. C. (2013). Um estudo sobre as características do método Delphi e de grupo focal, como técnicas na obtenção de dados em pesquisas exploratórias. Rev Administ Univers Fed Santa Maria, 6(1), 9-24. https://doi.org/10.5902/198346596243

Marques, J. P. D. H., Costa, L. B., Pinto, A. P. D. S., Lima, A. F. D., Duarte, M. E. L., Barbosa, A. P. F., \& Medeiros, P. L. D. (2011). Células glandulares atípicas e câncer de colo uterino: revisão sistemática. Rev. Assoc. Med. Bras., 57(2), 234-238. https://doi.org/10.1590/S0104-42302011000200024

Medeiros, R. K. S., Ferreira, M. A., Pinto, D. P. S. R., Vitor, A. F., Santos, V. E. P., \& Barichello, E. (2015). Modelo de validação de conteúdo de Pasquali nas pesquisas em Enfermagem. Revista de Enfermagem, Coimbra - Portugal, 4(4), 127-135. http://dx.doi.org/10.12707/RIV14009

Melo, R. P., Moreira, R. P., Fontenele, F. C., Aguiar, A. S. C., Joventino, E. S., \& Carvalho, E. C. (2011). Critérios de seleção de experts para estudos de validação de fenômenos de enfermagem. Rev Rene. 12(2), 424-31. http://repositorio.ufc.br/bitstream/riufc/4007/1/2011 artascaguiar.pdf. 
Mendes, P. H. C., Martelli, D. R. B., Souza, W.P., Quirino, S., \& Martelli, H. (2010). Perfil dos pesquisadores bolsistas de produtividade científica em medicina no CNPq, Brasil. Rev Bras Educ Médica. 34(4), 535-541. https://doi.org/10.1590/S0100-55022010000400008.

MILLER, A. B. (2016). Devemos continuar a fazer exames de papanicolaou em mulheres que não têm mais colo do útero?. American Journal of Public Health. 106(11), 1900-1901. https://doi.org/10.2105/ajph.2016.303411

Moscicki, A. B., Flowers, L., Huchko, M. J., Long, M. E., MacLaughlin, K. L., Murphy, J., Spiryda, L. B., \& Gold, M. A. (2019). Guidelines for Cervical Cancer Screening in Immunosuppressed Women Without HIV Infection. Journal of Lower Genital Tract Disease. California - Los Angeles, 23(2), 87101. http://dx.doi.org/10.1097/LGT.0000000000000468

Morais, A. M. E., Morais, C. F., Morais, C. E., Anghebem, M. I. O., \& Merlin, J. C. (2011). ASC-US: uma revisão da literatura para responder aos problemas práticos do dia a dia do citologista. Rev Bras Análises Clínicas. Recife-PE, 43(4), 309-320. https://www.ccecursos.com.br/img/resumos/esfrega-o-atr-fico-umdesafio---rotina-do-citologista-tcc---ramylla-duarte-costa-lima.pdf.

Moreira, C. B., Bernardo, E. B. R., Catunda, H. L. O., Aquino, P. S., Santos. M. C. L., \& Fernandes, A. F. C. (2013). Construção de um Vídeo Educativo sobre Detecção Precoce do Câncer de Mama. Revista Brasileira de Cancerologia. Fortaleza-CE. 59(3), 401-407. https://doi.org/10.32635/21769745.RBC.2013v59n3.505

Moura, I. H., Silva; A. F. R., Rocha, A. E. S. H., Lima, L. H. O., Moreira, T. M. M., \& Silva, A. R. V. (2017). Construction and validation of educational materials for the prevention of metabolic syndrome in adolescentes. Rev. Latino-Am. Enfermagem. Teresina - PI. 25. https://doi.org/10.1590/15188345.2024 .2934

Nayar, R., \& Wilbur, D. C. (2015). The Bethesda System for Reporting Cervical Cytology. Definitions, Criteria, and Explanatory Notes. Switzerland. 3, XXIV, 321. https://doi.org/10.1007/978-3-319-11074-5

Oliveira, G. G., Oliveira, J. M. S. C., Eleutério, R. M. N., \& Eleutério, J. (2018). Management of Atypical Squamous Cell Cases: A Prospective Study of Women seen at a Private Health Service in Northeastern Brazil. Rev Bras Ginecol Obstet. Fortaleza - CE. 40(3), 121-126. https://doi.org/10.1055/s-00381639466.

Onu - Organização das Nações Unidas. (2019) Transformando nosso mundo: A Agenda 2030 para o Desenvolvimento Sustentável. Brasília - DF. Disponível em: https://nacoesunidas.org/pos2015/agenda2030/.

Paula, P. F.; Anjos, S. J. S. B., Sousa, C. S. P., Pinheiro, P. N. C.,,Pinheiro, A. K. B., \& Aquino, P.S. (2016). Música como tecnologia na prevenção do câncer de colo uterino / Music as technology in cervical cancer prevention. Ciência, Cuidado e Saúde, 15(1), 180 - 186. https://doi.org/10.4025/cienccuidsaude .$v 15$ i 1.24483

Pasquali, L. (2017) Psicometria: teoria dos testes na psicologia e na educação. Vozes. 5, 392.

Peuker, A.C.; Lima, N.B.; Freire, K.M.; Oliveira, C. M. \& Castro, E. K. (2017). Construção de um material educativo para a prevenção do câncer de colo do útero. Estudos Interdisciplinares em Psicologia. Londrina/PR. 8(2), 146-160. http://pepsic.bvsalud.org/scielo.php?script=sci_arttext\&pid= S223664072017000200009\&lng=pt\&tlng=pt.

Primo, C. C.; Plaster, F. A., Bravin,M.F., Leite, F. M. C., \& Almeida, E. F. (2012). Perfil epidemiológico de mulheres submetidas a cirurgia na unidade de ginecologia de um hospital universitário. Rev. Min. Enferm. Vitória-ES, 16(4), 494-501. http://reme.org.br/artigo/detalhes/553.

Richardson, R. J. (2017). Pesquisa Social: métodos e técnicas. Atlas. 4. https://docero.com.br/doc/x0101c.

Rubio, D. M., Weger. M. B., Tebb, S. S., Lee, S., \& Rauch, S. (2003). Objectifying content validity: conducting a content validity study in social work research. Soc Work Res. 27(2), 94-105. https://doi.org.10.1093/swr/27.2.94

Sanderson, S., Suckiel, S., Zweig, M., Bottinger, E. P., Jabs, E. W., \& Richardson, L. D. (2016). Development and preliminary evaluation of an online educational video about whole-genome sequencing for research participants, patients, and the general public. Genet Med.18(5), 501-512. https://doi.org/10.1038/gim.2015.118

Rosendo, D. A., Santos, C. M., Ferreira, G. M., Canello, L. M., \& Colonelli, D. E. (2018). Células escamosas atípicas de significado indeterminado (ASC-US): seguimento de exames analisados no Instituto Adolfo Lutz / Atypical squamous cells of indeterminate significance (ASC-US): follow-up of assay in Instituto Adolfo Lutz. Rev. bras. anal. clin. São Paulo - SP. 50(3), 265-269. https://doi.org/10.21877/2448-3877.201800680

Salvador, M. T. C. O., Mariz, C. M. S., Vítor, A. F., Ferreira, M. A., Fernandes, M. I. D., Martins, J. C. A., \& Santos, V. E. P. (2018). Validação de objeto virtual de aprendizagem para apoio ao ensino da sistematização da assistência de enfermagem. Rev Bras Enferm. 71(1), 16-24. https://doi.org/10.1590/00347167-2016-0537

Serour Y., Bendahmane, M., Baker, F. A., Medles, M., Moueddene, B., \& Kraiba, R. (2017). HPV test by Hybrid Capture II for the diagnosis of HR-HPV persistent infection. Med Mal Infect. 47(7), 484-489. https://doi.org/10.1016/j.medmal. 2017.05.013

Silva, I. D., Silva, M. E. T., Andrade, J. S. O., Nunes, B. C. M., \& Pego, C.O. (2019). Exame papanicolau: percepção das mulheres sobre os motivos que influenciam a sua não realização. Revista Eletrônica Acervo Saúde, 34, e1125. https://doi.org/10.25248/reas.e1125.2019

Silva, R.S., Pereira, A., Nóbrega, M. M. L., \& Mussi, F. C. (2017). Construção e validação de diagnósticos de enfermagem para pessoas em cuidados paliativos. Rev. Latino-Am. Enfermagem. Salvador - BA. 15, e2914. https://doi.org/10.1590/1518-8345.1862.2914.

SOUSA, D. M. N., Chagas, A. C. M. A., Vasconcelos, C. T. M., Stein, A. T., \& Oriá, M. O. B. (2018). Development of a clinical protocol for detection of cervical cancer precursor lesions. Rev. Latino-Am. Enfermagem. Fortaleza, CE. 26, 1518-8345. https://doi.org/10.1590/1518-8345.2340.2999

Tsunechiro, M. A., Bonadio, I. C., Garcia, A. P. F., \& Pina-Oliveira, A. A. (2002). O jogo educativo como recurso para prevenção do câncer de colo do útero. An. 8 Simp.. Bras. Comum. Enferm. Ribeirão Preto - SP: EERP-USP. http://www.proceedings.scielo.br/scielo.php?pid=MSC00000000 $52002000200026 \&$ script=sci_arttext $\&$ tlng=pt. 
Research, Society and Development, v. 11, n. 1, e45511125096, 2022

(CC BY 4.0) | ISSN 2525-3409 | DOI: http://dx.doi.org/10.33448/rsd-v11i1.25096

Valente, C. A., Andrade, V., Soares, M. B. O., \& Silva, S.R. (2015). Atividades educativas no controle do câncer de colo do útero: relato de experiência. Revista de Enfermagem do Centro Oeste Mineiro, Universidade Federal de São João del-Rei. 5(3). http://https://doi.org/10.19175/recom.v5i3.576

Virla, M. Q. (2010). Confiabilidad y coeficiente Alpha de Cronbach. Telos, 12(2), 248-252. https://www.redalyc.org/articulo .oa?id=99315569010.

Who - World Health Organization. Human papillomavirus (HPV) and cervical câncer. (2019). https://www.who.int/en/news-room/fact-sheets/detail/humanpapillomavirus-(hpv)-and-cervical-cancer

Wynd, C. A., Schmidt, B., \& Schaefer, M. A. (2003). Two quantitative approaches for estimating content validity. West J Nurs Res. 25(5), 508-18. $10.1177 / 0193945903252998$.

Zeferino, L. C., Bastos, J. B., Vale, D. B. A. P., Zanine, R. M., Melo, Y. L. M. F., Primo, W. Q. S. P.; Corrêal, F. M., Val, I. C. C., \& Russomano, F. (2018). Guidelines for HPV-DNA. Testing for Cervical Cancer Screening in Brazil. Rev Bras Ginecol Obstet. São Paulo-SP. 40(6) 360-368. https://doi.org/10.1055/s0038-1657754. 